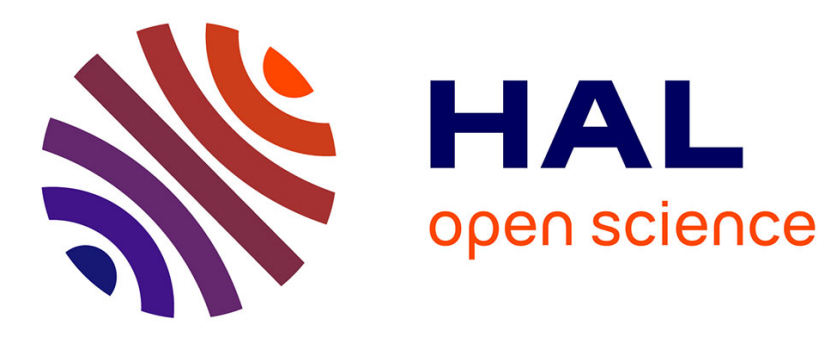

\title{
Rare fossil polychelid lobsters in turbiditic palaeoenvironments
}

Denis Audo, Sylvain Charbonnier, Michal Krobicki

\section{To cite this version:}

Denis Audo, Sylvain Charbonnier, Michal Krobicki. Rare fossil polychelid lobsters in turbiditic palaeoenvironments. Journal of Systematic Palaeontology, 2018, 16 (12), pp.1017-1036. 10.1080/14772019.2017.1359690 . hal-01961013

\section{HAL Id: hal-01961013 https://hal.sorbonne-universite.fr/hal-01961013}

Submitted on 19 Dec 2018

HAL is a multi-disciplinary open access archive for the deposit and dissemination of scientific research documents, whether they are published or not. The documents may come from teaching and research institutions in France or abroad, or from public or private research centers.
L'archive ouverte pluridisciplinaire HAL, est destinée au dépôt et à la diffusion de documents scientifiques de niveau recherche, publiés ou non, émanant des établissements d'enseignement et de recherche français ou étrangers, des laboratoires publics ou privés. 


\title{
Rare fossil polychelid lobsters in turbiditic palaeoenvironments
}

Denis Audo ${ }^{\mathrm{a}, \mathrm{b}}$, Sylvain Charbonnier ${ }^{\mathrm{b}}$, Michał Krobicki ${ }^{\mathrm{c}, \mathrm{d}}$

aUMR CNRS 6118 Géosciences, Université de Rennes I, Campus de Beaulieu, avenue du général Leclerc, 35042 Rennes cedex, France;

${ }^{\text {b} M u s e ́ u m ~ n a t i o n a l ~ d ’ H i s t o i r e ~ n a t u r e l l e, ~ C e n t r e ~ d e ~ R e c h e r c h e ~ s u r ~ l a ~ P a l e ́ o b i o d i v e r s i t e ́ ~ e t ~ l e s ~}$ Paléoenvironnements (CR2P, UMR 7207), Sorbonne Universités, MNHN, UPMC, CNRS, 57 rue Cuvier F-75005 Paris, France;

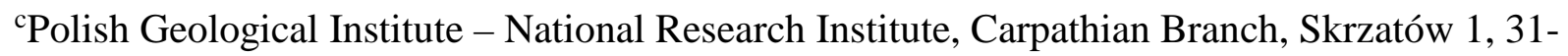
560 Kraków, Poland;

${ }^{\mathrm{d} A G H}$ University of Science and Technology, Department of Geology, Geophysics and Environmental Protection, Mickiewicza 30, 30-059 Kraków, Poland.

\begin{abstract}
Polychelidan lobsters are one of the rare groups of decapod crustaceans which were first discovered as fossils long before being identified in extant deep-sea environments. As other decapods, their fossil record is highly incomplete, which complicates the reconstruction of their evolutionary history. Another problem hinders a better knowledge of the group: the familial assignments, which can be difficult in the absence of a complete revision of known fossil taxa. As a result, only three fossil Polychelidae have been identified to date, the oldest dating back to the Callovian (Middle Jurassic). In the present study, we consider two rarely studied species, Palaeopolycheles crymensis Levitski, 1974 from the Toarcian-Aalenian (Early-Middle Jurassic) of Crimea (Ukraine), and Eryon neocomiensis Woodward, 1881 from
\end{abstract}


the Valanginian (Early Cretaceous) of the Outer Carpathians (Czech Republic). Our reinvestigations indicate they present several characters typical of Polychelidae, and are actually morphologically quite similar to extant species, notably in the structure of the anterior part of carapace and the small ocular incisions. Two new genera are erected to accommodate them: Tauricheles nov. gen., and Woodwardicheles nov. gen. These reinvestigations show that: (1) the evolutionary history of Polychelidae is much older; (2) Polychelidae have inhabited deep-water for a long time; (3) both species are probably autochthonous or parautochthonous to turbiditic palaeoenvironments; (4) Woodwardicheles neocomiensis nov. comb. is one of the rare benthic macrofossil of the Silesian Basin.

Keywords: Exceptional preservation; crustacea; Crimea; Czech Republic; Early-Middle Jurassic; Early Cretaceous.

\section{Introduction}

"The depth of the world ocean are home to the eyeless, claw-footed polychelids, "living fossils”, kin to the long vanished eryonids, tracing their ancestry back as far as the Mesozoic.” Bella S. Galil, 2000.

Polychelidan lobsters are one of the rare groups of decapod crustaceans - with glypheidean lobsters (Desmarest 1817, Charbonnier et al. 2013) - which were first discovered in the fossil record before being identified in modern deep-sea environments (Heller 1863).

Polychelidan lobsters (Polychelida Scholtz \& Richter, 1995) are easily identified by their dorsoventrally flattened carapace (= shield), their reduced rostrum, and their chelate pereiopods 1 to 4 (= thoracopods 4 to 7 ). These traits were already present in the earliest known members of the group which occur in the Late Triassic (Förster 1967, Karasawa et al. 2003). Surprisingly, fossil polychelidan lobsters seem to be morphologically more diverse 
than their extant relatives (Audo et al. 2014c). This higher morphological diversity is also linked to higher habitat diversity. Indeed, while extant species are restricted to deep-sea environments (Galil 2000, Ahyong 2009), fossil species are documented from shallow water palaeoenvironments (Garassino \& Schweigert 2006, Ahyong 2009, Audo et al. 2014a, 2014b, Bravi et al. 2014) to deep palaeoenvironments (Charbonnier 2009, Charbonnier et al. 2010, 2014, Audo et al. 2014c). This suggests their diversity was reduced by one, or more probably several extinction events, possibly starting at the end of Jurassic, when they became extremely rare in the fossil record (Garassino et al. 2012, Haug et al. 2015).

One of the issues when studying the evolutionary history of polychelidan lobsters is the discontinuity in their fossil record. For instance, Proeryon Beurlen, 1928 is well-documented during the Middle Jurassic (Audo et al. 2014c) and seems to vanish entirely until the Early Cretaceous (Schweigert \& Herd 2010); polychelidans seem to disappear after the Cenomanian (or even earlier, depending on the interpretation of Lebanese fossils described by Haug et al. 2015), might be represented by a fragment of appendage of the early Miocene (Rathbun 1919), and then "seem to reappear" in the modern fauna. Despite these complications, and based upon the first phylogenetic analysis including fossil polychelidans, Ahyong (2009) was the first to propose an interpretation of their evolutionary history. For him, the Coleiidae Van Straelen, 1925 displayed a shift to live in deeper environments. This shift could explain why extant Polychelidae are now deep-sea inhabitants. However, it is important to indicate that at the time, Ahyong (2009) only considered one fossil species, Antarcticheles antarcticus Aguirre-Urreta, Buatois, Chernoglasov \& Medina, 1990, as a member of the Polychelidae. Polychelidae seems extremely rare in the fossil record. It is probable that the preservation potential of polychelidans plays an important role in their rarity. Another important factor might also be the recognition of polychelidans in the fossil record. Indeed, the systematics of polychelidan lobsters is still far from being resolved. Is it possible that other fossils of 
Polychelidae would give a slightly different view of the evolutionary history of polychelidans?

\section{Extant Polychelidae}

The first extant Polychelidae to be discovered were not immediately recognized as relatives of fossil polychelidans (notably to the well-known Eryon cuvieri Desmarest, 1817). Indeed, Heller (1862) and Willemoes-Suhm in Wyville Thompson (1873a) did not recognize the affinities of the first species they described at first. Yet, both realized soon after the significance of their discoveries (Heller 1863, Willemoes-Suhm in Wyville Thompson 1873b - note that Willemoes-Suhm in Wyville-Thompson 1873a, 1873b do not refer to Heller works). Soon after, the family Polychelidae was erected to accommodate extant species (Wood-Mason 1874).

All extant polychelidan lobsters are included within a single family, the Polychelidae with thirty-nine extant species in six genera which are known worldwide (Galil 2000, Ahyong \& Brown 2002, Ahyong \& Galil 2006, Ahyong \& Chan 2008, Ahyong 2009, Chan et al. 2011, Artüz et al. 2014). All have strongly reduced eyes, and they are adapted to deep-water environments, and are therefore sometimes referred to as “deep-sea blind lobsters” (Dall’Occo \& Tavares 2004, Chang et al. 2013, Bezerra \& Bezerra Ribeiro 2015, Farias et al. 2015) and all of them are restricted to outer slope or abyssal depth (Ahyong 2009, 2012), although rare cases occur as high as $77 \mathrm{~m}$ depth (Galil 2000). On average, adult polychelids are most frequently discovered on the sea-bottom from $500 \mathrm{~m}$ to $1500 \mathrm{~m}$ (maximum up to $5000 \mathrm{~m}-$ Galil 2000).

Due to their deep-sea dwelling habits, little is known of their life-habits. Most species seem to be opportunistic scavengers (Firth \& Pequegnat 1971, Gore 1984, Cartes \& Abellò 1992), sometimes with more predatory habits (Lagardère 1973). They also seem to be able to bury 
themselves into the sediment, perhaps to avoid predators and to ambush preys (Santucci 1933, Firth \& Pequegnat 1971, Ahyong 2009). This burying behaviour could explain why they remain rarely observed by Remotely Operated Vehicles (ROV) or camera (Firth \& Pequegnat 1971). One of the rare pictures of a live polychelid in its natural environment also shows an animal that seem to have been startled from its semi-buried position by a ROV (Jones et al. 2009).

\section{Fossil Polychelidae in the literature}

Unfortunately, most palaeontological studies did not include, or only superficially, extant species. Similarly, studies on extant species generally did little more than mentioning the existence of fossil forms.

Glaessner (1969) was the first, to our knowledge, to assign fossil taxa to Polychelidae: Palaeopentacheles Knebel, 1907 (one species), Palaeopolycheles Knebel, 1907 (one species at the time) and Willemoesiocaris Van Straelen, 1925 (one species). Afterwards, two other fossil species were added to the family: Palaeopolycheles crymensis Levitski, 1974 and Antarcticheles antarcticus (Levitski 1974, Aguirre-Urreta et al. 1990). From that point on, species were gradually removed from Polychelidae: Palaeopolycheles longipes was ascribed to Coleia Broderip, 1835 by Schweigert \& Dietl (1999) - who did not considered the case of Palaeopolycheles crymensis Levitski, 1974. Ahyong (2009) ascribed Palaeopentacheles to the Palaeopentachelidae Ahyong, 2009 and Willemoesiocaris to the Coleiidae, leaving Antarcticheles antarcticus as the only fossil species ascribed to Polychelidae. Schweitzer et al. (2010) proposed a list of fossil decapods, including polychelidans, which included aforementioned taxonomic opinions except Ahyong (2009). It also listed Palaeopolycheles crymensis as incertae sedis within Polychelidae. Feldmann et al. (2013) maintained Antarcticheles and Willemoesiocaris within Polychelidae. More recently, Audo et al. (2014c) considered Palaeopolycheles to be distinct from Coleia, stressed the similarities of 
Palaeopolycheles and Willemoesiocaris, considering both of them as Coleiidae and added Hellerocaris Van Straelen, 1925 to Polychelidae. Finally, Haug et al. (2015) described fossil crustaceans they interpreted as large eryoneicus-like larvae. These fossils were interpreted as eryoneicus-like larvae mainly based upon the highly spinose exoskeleton and the apparently chelate pereiopods 2 to 4 . These characters, if correctly interpreted, support an identification as an eryoneicus-type larvae (see Bernard 1953 for description of modern eryoneicus). However, this interpretation is currently being challenged (S.T. Ahyong and F. Palero pers. comm. 2017), and a revision is needed to shed light on these fossils exact affinities.

In conclusion, at the time of writing, only two fossil species - Hellerocaris falloti (Van Straelen, 1923) and Antarcticheles antarcticus - and perhaps an unnamed fossil larva are considered as fossil representative of the Polychelidae. A third species, Palaeopolycheles crymensis is in a state of "taxonomic limbo": assigned without justification to Polychelidae, yet, placed within a genus which type species was revised twice and is not assigned to Polychelidae anymore.

\section{Aim of the study}

The present work derives directly from the research performed for the preparation of a phylogenetic study of the fossil and extant polychelidan lobsters. It focuses on two poorly known species presenting a typical Polychelidae habitus and therefore undoubtedly representing fossil relatives of extant species: Palaeopolycheles crymensis from the EarlyMiddle Jurassic of Crimea (Ukraine) and Eryon neocomiensis Woodward, 1881 from the Early Cretaceous of Czech Republic. 


\section{Material and methods}

\section{Material}

The present study is based on two specimens: the holotype of Palaeopolycheles crymensis and the holotype of Eryon neocomiensis. Both are the single known occurrence of their respective species.

The holotype of Palaeopolycheles crymensis comes from the Yaman ravine near Mangush village (Prokhladnoe), Bakhchysarai region, Crimea. The age of the outcrop what estimated as Toarcian-Aalenian based upon the occurrences of Dactylioceras sp. and Mesoteuthis quenstedti Oppel, 1856. The current stratigraphic extention of Acrocoelites (Toarcibelus) quenstedti (Oppel, 1856) (current generic assignment for M. quenstedti) is now considered to span from the early Toarcian to the Aalenian (Doyle 1991). To our knowledge, the counterpart of the fossil is not available. The fossil is housed at the Gosudarstvenniy Geologicheskiy Musey - State Geological Museum, Moscow, Russia, under collection number GGM VI-165/1.

The holotype of Eryon neocomiensis has been discovered by Ludwig Hohenegger in February 1863 and named by him as Eryon Neocomiensis (sic!) and is stored now in Bavarian State Collection of Palaeontology and Geology (Bayerische Staatssammlung für Paläontologie und Geologie) in Munich (Germany) (see - Woodward 1881) under collection number SNSBBSPG AS I 994.

Comparison material of Palaeopentacheles longipes (Fraas, 1858) is housed in the Staatliches Museum für Naturkunde, Stuttgart, Germany. It includes the lectotype SMNS 64001, the paralectotypes SMNS 3682, 6197/1, 6197/2, and additional specimens SMNS 63260, 63595, 63724, 63744, 63833, 70203. 


\section{Imagery}

The holotype of Palaeopolycheles crymensis was imaged by a flatbed scanner.

The holotype of Eryon neocomiensis was imaged by Joachim T. Haug (Ludwig-MaximiliansUniversität) using cross-polarized light, to increase contrast of the specimen against the matrix (Bengtson 2000, Haug et al. 2011). The red channels of the part and counterpart images were combined to provide an enhanced image of the specimen (Haug et al. 2009).

Specimens of Palaeopolycheles longipes were also photographed under cross-polarized light and natural, unpolarised light.

\section{Institutional abbreviations}

GGM, Gosudarstvenniy Geologicheskiy Musey - State Geological Museum, Moscow, Russia; SMNS, Staatliches Museum für Naturkunde, Stuttgart, Germany; SNSB-BSPG, Bayerische Staatssammlung für Paläontologie und Geologie, Munich, Germany.

\section{Geological context and preservation}

\section{Preservation of Palaeopolycheles crymensis}

Palaeopolycheles crymensis is known for a single specimen from Yaman ravine (Crimea, Fig. 1). The holotype of Palaeopolycheles crymensis is preserved within a sideritic concretion which was compressed by diagenesis. Only one part of the nodule is known (Fig. 2), which offers a view of the inner side of the cephalothorax tergite (carapace), pleon and telson (as if looked from inside the animal). Additionally, fragments of cephalic appendages, the first pair of pereiopod and uropods are preserved. The specimen is articulated and subcomplete. In fact, missing parts where perhaps either preserved on the missing part of the sideritic nodule or still concealed by sediment. From a taphonomical point of view, crustacean decapods need very special conditions, including limited post-mortem transport, relatively rapid burial and lack of 
bioturbation in the sediment (Plotnick 1986, Plotnick et al. 1988, Müller et al. 2000). It is therefore possible that this specimen was autochthonous or parautochthonous of the environment where it fossilized. The position of the fossil, with first pereiopods which are not tucked tightly against carapace margins corresponds to the position in which most of the fossil polychelidans, exuvia and body fossils are discovered. It could even correspond to a semiburied position, with appendages held above the carapace, which was observed in live specimens in aquarium (Higashiji pers. comm. 2013, see fig. 6 of Jauvion et al. 2016; note however that specimens in aquarium does not seem to have a normal behaviour, see also Santucci 1933). It is therefore difficult to know to which type of rest the holotype of $P$. crymensis corresponds, especially so that exuvia are often confused with body fossils (Schweigert 2007a, Audo et al. 2014a, Audo 2016). We however note that it seems unlikely that this fossil corresponds to an exuvia since the median line seems to be intact and does not present any tearing typical of exuvia (Audo 2016).

\section{Origin and age of Palaeopolycheles crymensis}

Palaeopolycheles crymensis Levitski, 1974 holotype was discovered in an outcrop of the Yaman ravine near Prokhladnoe village (Bakhchysarai region, Crimea, Ukraine: Fig. 1). This locality is also known for its stratotype section of the Taurida Flysch Formation (sensu Oszczypko et al. in press) of Late Triassic - Early Jurassic age (Muratov 1960, Muratov et al. 1984). Recent micropalaeontological studies based on foraminiferal assemblages and calcareous nannoplankton (Oszczypko et al. in press) generally confirm Early Jurassic age (Toarcian-Aalenian) of the uppermost part of flysch-type sequence in this region (Nikishin et al. 2015). This age corresponds to what Levitsky (1974) proposed based upon the occurrence of the belemnite Acrocoelites (Toarcibelus) quenstedti (Oppel, 1856) (see Doyle 1991 for the current taxonomic placement and stratigraphic interval of this species). 
Sideritic concretions such as that preserving $P$. crymensis holotype (Fig. 2A-D), are typical for dark grey, fine to very fine, thin- to medium-bedded turbiditic sandstones with shaly and mudstone intercalations and rare thick sandstone beds. In this case we have typical, deep-sea flysch-type deposits which very well documented syn-orogenic character of the Jurassic Crimean trough regime during sedimentation of turbidites.

\section{Preservation of Eryon neocomiensis}

Eryon neocomiensis is known from a single specimen from Dolní Líštná (Czech Republic:

Fig. 3). The holotype of Eryon neocomiensis is preserved flattened dorsoventrally. The surrounding sediment is dark brown and the fossil appears slightly darker (Fig. 4). The matrix appears to be a flyschoidal-type of fine-grained mudstones of turbiditic origin.

Sedimentological features of hosted rock, visible on a perpendicular cross-section to the bedding surface with crustacean specimen, indicate thin, convolute lamination of crossbedding structure in minor scale, which have to be interpreted as typical ripplemark structure of turbiditic origin (Fig. 5). Additionally, very small muscovite grains occur abundantly on the bedding surfaces. Finally, the brown color of rock (by Woodward described as "hard black bituminous-looking limestone” - Woodward 1881: 531) in fact is effect of later process of sideritization, which was evidently similar in the cases of associated ammonites from similar rocks in the vicinity: Busnardoites campylotoxus (Uhlig, 1902) and Hoplites neocomiensiformis Uhlig, 1902.

The holotype of E. neocomiensis is exceptionally preserved complete with very fine details such as minute spines on the scaphocerite and antenna. Such an exceptional preservation is rare, especially within such fine-grained quartzite mudstones. As for the holotype of $P$. crymensis, the holotype of $E$. neocomiensis is preserved in the disposition the most frequently observed for fossil polychelidans, with the first pereiopods parallel to the carapace, but not pressed against it. As discussed for P. crymensis, the holotype of E. neocomiensis may 
represent an exuvia or a body fossil, in this later case, possibly in life-position. The median line is not well-preserved enough (probably slightly damaged when the stone was split open) to assess if it was opened as in exuvia (Audo 2016), however, there is no mismatch on either side, suggesting it was in fact intact. Interestingly, dark stains are visible under the carapace and might correspond to organic matter. If this hypothesis is true, then this fossil is undoubtedly a body fossil, not an exuvia. As for P. crymensis, the preservation of the specimen suggests it is undoubtedly autochthonous or parautochthonous of its deposition environment.

Sediments deposited on low-energy conditions (Schäfer 1951) and mainly from suspension are preferable for decapods conservation. Rapid burial is necessary against short time which is needed for decomposition and disintegration of crustacean bodies and which are limited to few days (example given for pandalid shrimps with residence time inferior to 9 days - Bishop 1986, Plotnick 1986). The holotype of E. neocomiensis therefore corresponds either to a corpse or an exuvia which was buried very rapid by a fine-grained silty mud from weak turbiditic suspension cloud. This suspension cloud was thin enough not to destroy this polychelid but protected it against destructive effects.

\section{Origin and age of Eryon neocomiensis}

Woodward (1881) refers to Hohenegger (1852) concerning the origin of the holotype of $E$. neocomiensis. According to Hohenegger's investigations in the Carpathian Mountains, Woodward (1881) mentioned its origin connected with "Neocomian of Niederlishna, Silesia” (Woodward 1881: 531). “Niederlishna” corresponds to the village of Dolní Líštná near Třinec in the Moravian part of Czech Republic (Fig. 3).

More precisely, Woodward (1881) associates E. neocomiensis to the Štramberk-type limestones (sensu - Kołodziej 2015a, 2015b), citing Hohenegger (1852) who indicates that 
these rocks can vary from white to blackish grey in colour. Woodward (1881) does not give any other information about the original locality or the fossil with which E. neocomiensis could be associated. Therefore, we are unable to precise the age and palaeoenvironment of origin of E. neocomiensis only from Woodward (1881).

The Štramberk-type limestones, that Woodward (1881) mention are dated into the latest Jurassic (Tithonian) - earliest Cretaceous (Early Berriasian). They are well-known for their abundant crustacean fauna coming from several localities: the so-called Ernstbrunn limestones in Austria (e.g., Bachmayer 1947, Schweitzer \& Feldmann 2009, Robins et al. 2012, 2013), from the Štramberk limestones in Czech Republic (active Kotouč quarry and its surrounding’s - Moericke 1889, Remeš 1895, Bachmayer 1959, Müller et al. 2000) and Štramberk-type limestones from the Polish Carpathians (mainly as exotics - sensu Kołodziej 2015a, 2015b, see also Krobicki \& Fraaije in press) (Patrulius 1966, Müller et al. 2000, Krobicki \& Zatoń 2008, 2016, Fraaije et al. 2013). However, no fossil polychelidan have been discovered from these localities yet, despite the research efforts that went into their study. The facies in which these crustaceans occur, whitish coral limestones, is also very different from the dark flyschoidal-type of fine-grained mudstones in which E. neocomiensis is preserved. The assertion by Woodward (1881) that E. neocomiensis comes from a Štramberk-type limestones outcrop and is coloured by bitumen impregnation seems unlikely and only rely on the anecdotic presence of darker rocks within Štramberk-type limestones.

As explained, we identified that “Niederlishna” corresponds to the village of Dolní Líštná in Czech Republic. Compared to flyschoidal mudstones of the vicinity, the matrix surrounding E. neocomiensis holotype is typical of Cisownica Shale Member of the Hradiště Formation (Golonka et al. 2008). The sedimentological character of this member possesses typical flysch features, including dark brown-grey, variable silt-sandy claystones and marly shale-type deposits intercalated with rare of thin-bedded fine-grained calcareous sandstones and 
mudstones, which represented classical fan-shape submarine lobes and their outer, more distal, parts of deep-sea turbiditic system (Malik \& Olszewska 1984, Halásová et al. 2012, Skupien et al. 2013). In the upper part of unit occur rare intercalations of debris-flows gravelstones with exotic pebbles and blocks (Malik \& Olszewska 1984). But the lowermost part of this member, stratigraphicaly corresponded to Lower Valanginian (Skupien et al. 2013), is dominated by claystones with very rare thin intercalations of mudstones and finegrained sandstones.

The Outer Western Carpathian, where Dolní Líštná is located, are dominated by Silesian Unit, as one of the main nappe of the Carpathian arc (Fig. 3). The Silesian Nappe is formed by Upper Jurassic - Oligocene-Miocene flysch-type sediments deposited originally in the Silesian Basin (Golonka et al. 2006, Picha et al. 2006,). Tectonically, this unit is subdivided to three subunits. In Moravian part of the Outer Carpathians of the Silesian Nappe, the socalled Godula Subunit occurs and is represented by very thick, up to $6000 \mathrm{~m}$, turbidite system which was sedimented as submarine fans in the continental rise setting. The deposits of this subunit are manifested by Late Jurassic-earlymost Cretaceous (?Oxfordian-early Berriasian) Vendryně Formation, previously distinguished as Lower Těšín (Cieszyn) Member of Eliáš et al. (2003), the Těšín (Cieszyn) Limestone Formation of Golonka et al. (2008) (early Berriasian-early Valanginian: Boorová et al. 2004) and Hradiště (Grodziszcze) Formation (earlier known as Těšín-Hradiště Formation) of early Valanginian - early Late Aptian (Skupien 1999, Skupien et al. 2013). Their chronostratigraphy is based on rare ammonites (Vašíček 1975, Skupien \& Vašíček 2002, Vašíček \& Skupien 2002) and dinoflagellate cyst assemblages (Skupien \& Smaržová 2011, Skupien et al. 2013). In the Dolní Líštná surroundings the Hradiště Formation is dominating, and especially its lower part, and which have been known earlier as Upper Těšín (Cieszyn) Shales (= Oberen Teschener Schiefer of Uhlig 1902 or Oberen Těšín-Schichten of Vašíček 1975; see also - Menčík 1983) belong 
recently to the Cisownica Shale Member of the Hradiště Formation (Golonka et al. 2008)

(Fig. 6). A few finds of ammonites in this interval are mainly connected with area between Třinec and Český Těšín, where Dolní Líštná and Dolní Třanovice are the most important (Fig. 3). The former one is type locality not only for Eryon neocomiensis but also for holotype of Busnardoites campylotoxus (Uhlig, 1902) ammonite (Vašíček 1975, 2010, Nikolov 1977, Baraboshkin \& Mikhailova 2000). It is not certain, that these fossils come from the same outcrop, but the large outcropping area of the Cisownica Shale Member of the Hradiště Formation in this area strongly suggest they are indeed co-occurring in the same area. It shall be noted that unfortunately, the ammonite B. campylotoxus species have often been both erroneously determined and misinterpreted (discussion in Reboulet et al. 2014, Company \& Tavera 2015 and references therein). Yet, B. campylotoxus remains one of the most valuable taxon to study the early Valanginian time in Mediterranean province. For a long time, until a few years ago, B. campylotoxus was used as an index taxon for the upper part of the Lower Valanginian (Busnardoites campylotoxus Zone - see Reboulet \& Atrops 1999, Hoedemaeker et al. 2003, Reboulet et al. 2006, Harding et al. 2011). However, following the $5^{\text {th }}$ meeting of the IUGS Lower Cretaceous Ammonite Working Group (the so-called Kilian Group), this zone was abandoned in the Mediterranean ammonite zonation (Reboulet et al. 2014) and new early Valanginian standard zonation has been proposed where Neocomites neocomiensiformis Zone was accepted as a middle part of the early Valanginian. After Reboulet (1996) the lectotype of Hoplites neocomiensiformis Uhlig, 1902 could be interpreted as the inner whorls of a macroconch of B. campylotoxus (Reboulet et al. 2014). Therefore these species would be synonymous. A proposal by Company \& Tavera (2013) to subdivide of this zone to two subzones - lower Baronnites hirsutus Subzone and an upper Valanginites dolioliformis Subzone was not accepted by the Kilian Group (Reboulet et al. 2014). Yet, the stratigraphical range of B. campylotoxus is limited to this upper subzone (Company \& Tavera 2015). In 
conclusion, if Eryon neocomiensis co-occurs with these ammonites, it should be considered as coming from the upper part of the middle early Valanginian $(=V$. dolioliformis Subzone of the $N$. neocomiensiformis Zone of the early Valanginian).

Palaeobiogeographical distribution of B. campylotoxus/N. neocomiensiformis has been very wide in the Tethys Ocean: it occurs in south-eastern France (Reboulet \& Atrops 1999), southeastern Spain (Company \& Tavera 1982, 2015), central Italy (Faraoni et al. 1997), Romania (Ţibuleac 2012, Grădinaru et al. 2016), Czech Republic (Uhlig 1902, Vašíček 1975), Slovakia (Vašíček 1995, 2010), Bulgaria (Nikolov 1977, Petrova 2012), south-western Crimea, Ukraine (Baraboshkin \& Mikhailova 2000), Hungary (Fözy et al. 2010, Bujtor 2013), Morocco (Ettachfini 2004). Wherever they occurs, their stratigraphical range is only limited to the middle part of the Early Valanginian (according to the newest biozonation scheme Reboulet et al. 2014, Company \& Tavera 2015).

\section{Systematic palaeontology}

Malacostraca Latreille, 1802

Decapoda Latreille, 1802

Pleocyemata Burkenroad, 1963

Reptantia Boa, 1880

Polychelida Scholtz \& Richter, 1995

Polychelidae Wood-Mason, 1874

Included extant genera. Cardus Galil, 2000; Homeryon Galil, 2000; Pentacheles Spence Bate, 1878; Polycheles Heller, 1862; Stereomastis Spence Bate, 1888; Willemoesia Grote, 1873. 
Included fossil genera. Antarcticheles Aguirre-Urreta, Buatois, Chernoglasov \& Medina, 1990; Hellerocaris Van Straelen, 1925; Tauricheles nov. gen.; Woodwardicheles nov. gen.

Emended diagnosis. Ocular incision laterally closed by the expansion of lateral margin; posterolateral angle short, not extending along pleon; axial carina on pleonites terga 2 to 5 cutting posterior transverse groove; third maxilliped with narrow ischium.

Tauricheles nov. gen.

1974 Palaeopolycheles Knebel; Levitski: 110-111, pl. 2 fig. 1, pl. 3 fig. 1 (pro parte).

2010 Palaeopolycheles Knebel; Schweitzer et al.: 45.

Type-species. Palaeopolycheles crymensis Levitski, 1974, by monotypy.

Included species. monospecific genus.

Distribution. Toarcian-Aalenian, Crimea (Ukraine) (Levitski 1974).

Etymology. Contraction from the ancient Greek “Tavpıк’̀” (= inhabitant of the Tauric peninsula, antique name of Crimea, from where the type species occurs) and of the suffix “cheles" from the ancient Greek " $\chi \eta^{\prime} \lambda \eta "$ (= claw of an arthropod), referring to the large chelate first pereiopods, and reminiscent of other genera of Polychelidae. Gender of the genus is masculine.

Diagnosis. Dorsoventrally flattened carapace subrectangular in outline in dorsal view; frontal margin slightly posterior to anterior angle of anterolateral margin; small U-shaped ocular incision; outer edge of ocular incision merged with anterior angle of anterolateral margin; 
cervical and postcervical incisions shallow; posterolateral angle not projecting along first pleonite; cervical groove cutting median line; cervical groove curved around median line; faint postrostral carina and anterior part of branchial carina; axial carina on pleonites cutting posterior transverse groove; slender first pereiopod; uropodal exopod in one part (no diaeresis).

Discussion. The frontal margin placed slightly posterior to ocular incision outer angle, small ocular incision, shallow cervical and postcervical incisions and absence of diaeresis of Tauricheles nov. gen. are all typical of Polychelidae. Tauricheles (Fig. 5F) also seems to possess a carina parallel to branchiocardiac groove, and its posterolateral angle does not project along the first pleonite, two other characters typical of Polychelidae. For these reasons, we propose to assign Tauricheles to Polychelidae. Within Polychelidae, Tauricheles differs from all genera but Hellerocaris by its ocular incision which is placed next to the anterior edge of anterolateral margin (outer edge of ocular incision distinct from anterolateral margin anterior angle in other genera). It differs from all genera but Eryon neocomiensis (see below) and Cardus Galil, 2000 by its cervical groove curved medially (straight in other genera). It also differs from all genera but Pentacheles Spence Bate, 1878 by its faint anterior part of branchial carina. Tauricheles also differs from all Polychelidae by its faint postrostral carina.

Tauricheles crymensis (Levitski, 1974) nov. comb.

(Figs 2A-D, G)

1974 Palaeopolycheles crymensis Levitski: 110-111, pl. 2 fig. 1, pl. 3 fig. 1.

2010 Palaeopolycheles crymensis Levitski; Schweitzer et al. 2010: 45.

2017 Palaeopolycheles crymensis Levitski; Audo et al.: 218. 
Type material. Holotype by monotypy: GGM VI-165/1 (Figs 2A-D).

Type locality. Yaman ravine near Mangush village (Prokhladnoe), Bakhchysarai region, Crimea, Ukraine.

Type age. Late Toarcian-Early Aalenian (Upper Tauric Formation: Levitski 1974, Nikishin et al. 2015, Oszczypko et al. in press).

Distribution. Only known in the type locality.

\section{Description.}

Outlines of carapace. Dorsoventrally flattened carapace, subrectangular in outline in dorsal view; frontal margin slightly posterior to anterior angle of anterolateral margin; small Ushaped ocular incision with outer edge merged with anterior angle of anterolateral margin and inner angle forming a short spine; anterolateral margin slightly rounded twice as long as mediolateral margin; very small and shallow cervical and postcervical incisions opening in the first third of lateral margin; straight mediolateral margin; posterolateral margin almost straight; posterolateral angle short, not extending along the first pleonite; posterior margin slightly concave, larger than frontal margin.

Carapace grooves and carinae. Deep and oblique cervical groove extending from cervical incision to median line, curving slightly before reaching median line and cutting median line; deep postcervical groove extending from postcervical incision to median line, interrupted by branchial carina, straight from the branchial carina to the median line, not cutting median line; gastro-orbital groove not preserved or absent; shallow branchiocardiac groove with a parallel carina, extending obliquely from the intersection of postcervical groove and branchial carina to the rear of carapace, approaching median line without cutting it; postrostral carina barely 
visible; postcervical carina only slightly raised; faint postorbital carina and/or anterior part of branchial carina (both carinae are often merged); posterior part of branchial carina straight.

Pleon and telson. Pleon and telson combined longer than carapace; pleon almost as wide as carapace; pleonite 1 shorter than others, with a poorly preserved tergum; pleonites 1 to 6 with dorsal part of terga subrectangular, with two transverse grooves and a raised median carina cutting posterior transverse groove; tergopleuron (lateral part of tergum) 1 to 6 poorly preserved; triangular telson rather elongate, strengthened by a pair of carina.

Eyes and cephalic appendages. Not preserved.

Thoracic appendages. Long and slender first pereiopod with merus about as long as carapace, propodus also elongate; other thoracic appendages not preserved.

Pleonal appendages. Uropod with a stocky basipod, endopod and exopod petaloid, as long as telson; uropodal exopod strengthened in one part, no diaeresis apparent; uropodal exopod also with a raised median longitudinal carina and a fainter submarginal carina; uropodal endopod with only one median longitudinal carina; pleopods 1 to 5 not preserved.

Ornamentation. Carapace with scattered small tubercles.

Discussion. Palaeopolycheles crymensis was described based upon a single specimen in 1973 (Fig. 2A, B), apparently in a field guide, which is unavailable and is not considered valid under ICZN (1999: art. 8, 9). Palaeopolycheles crymensis is however validly published in 1974 (Levitski 1974). Levitski (1974) compares P. crymensis to Palaeopolycheles Knebel, 1907 (type species: Eryon longipes Fraas, 1855) and considered both species allied based upon of a marked postcervical groove, the presence of lateral carinae on carapace (= branchial carinae), the presence of an axial carina on pleonites terga and similarities in the 
ornamentation. Levitski (1974) also compared P. crymensis to Hellerocaris on the basis of the absence of diaeresis (although the diaeresis is present in Hellerocaris: see Audo 2014c). Levitski (1974) finally assigned P. crymensis to Palaeopolycheles.

Our reinvestigation of the holotype of Palaeopolycheles crymensis and comparison with all the available material of Palaeopentacheles longipes (see well-preserved specimen in Fig. 5D) lead us to reconsider generic assignment of $P$. crymensis. Indeed, most characters listed by Levitski (1974) are common within polychelidans: the branchial carina is generally wellmarked, Rogeryon oppeli (Woodward, 1866) being an exception (Audo et al. accepted); the postcervical groove is marked in Coleiidae Van Straelen, 1925, Polychelidae and Tetrachelidae Beurlen, 1930. The axial carina on pleonite terga is documented for all known species of polychelidan lobsters. Finally, the ornamentation of $P$. crymensis is composed of very thin tubercles quite dispersed on the carapace and pleon, while that of $P$. longipes is composed of larger tubercles placed next to each other. While characters uniting $P$. crymensis to $P$. longipes are weakly informative at best, both species however differ distinctly on many other aspects: (1) the frontal margin of $P$. crymensis seems to be placed slightly posteriorly to the outer angle of ocular incision (placed almost anteriorly to the ocular incision in $P$. longipes), (2) the ocular incision of P. crymensis is very small and U-shaped (large and widely open laterally in $P$. longipes), (3) the cervical and postcervical incisions of $P$. crymensis are shallow, forming a barely visible notch in lateral margin (excavated in $P$. longipes), (4) the branchial carina anterior to cervical groove is poorly faint in $P$. crymensis (well-marked in P. longipes), (5) the axial carina on pleonite terga cutting posterior transverse groove in $P$. crymensis (cut by a thin transverse groove in P. longipes), and (6) the uropodal exopod appears to be in one part in P. crymensis (divided by a diaeresis in P. longipes).

The differences between the two species justify that $P$. crymensis cannot be assigned to Palaeopolycheles (Fig. 2F) and justify the erection of Tauricheles nov. gen. to accommodate 
it. We therefore propose the new combination, Tauricheles crymensis (Woodward, 1881) nov. comb.

Woodwardicheles nov. gen.

1881 Eryon Desmarest; Woodward: 530-533, pl. 14 fig. 1. (pro parte)

1911 Eryon Desmarest; Woodward: 307. (pro parte)

1924 Eryon Desmarest; Balss: 175. (pro parte)

1925 Eryon Desmarest; Van Straelen: 442. (pro parte)

1929 Eryon Desmarest; Glaessner: 166. (pro parte)

1930 Eryon Desmarest; Chernyshev: 376. (pro parte)

1944 Eryon Desmarest; Roger: 193. (pro parte)

1968 Eryon Desmarest; Pinna: 106. (pro parte)

2006 ?Eryon Desmarest; Garassino \& Schweigert: 30.

2010 Eryon Desmarest; Schweitzer et al.: 43. (pro parte)

2012 Eryon Desmarest; Garassino et al.: 53. (pro parte)

2014c Eryon Desmarest; Audo et al.: 495. (pro parte)

Type-species. Eryon neocomiensis Woodward, 1881, by monotypy (Fig. 6A, C, E). 
Included species. monospecific genus.

Distribution. Valanginian (Early Cretaceous), Czech Republic (Woodward 1881).

Etymology. Dedicated to the English palaeontologist Henry Woodward who described the type species of this genus and greatly contributed to the early study of polychelidan lobsters. Gender of the genus is masculine.

Diagnosis. Dorsoventrally flattened carapace, pyriform in outline in dorsal view, wider anteriorly; frontal margin straight and smooth; frontal margin placed slightly posteriorly to anterolateral margin anterior angle; very small ocular incision; outer border "angle” of ocular incision distinct from the most anterior point of lateral margin; cervical groove curving near median line; branchial carina aligned on each side of cervical groove; posterolateral angle not extending along first pleonite; second pleonite tergopleuron covering first pleonite tergopleuron; uropodal exopod in one part (no diaeresis).

Discussion. Woodwardicheles nov. gen. is represented by a single species: Eryon neocomiensis. At the time of E. neocomiensis description, Woodward (1881) only recognized a single genus of fossil polychelidan, Eryon Desmarest, 1817 (Fig. 4D), so the generic assignment was realized "by default”. Since the description of E. neocomiensis, most species assigned to Eryon by Woodward $(1866,1877,1881,1888,1911)$ have been assigned to other genera. Eryon neocomiensis, which has not been revised since then has remained within Eryon, although Garassino \& Schweigert (2006) doubted this generic assignment.

Woodwardicheles nov. gen. does not present the diagnostic characters of Eryon and Eryonidae such as a carapace subhexagonal in outline in dorsal view, an ocular incision placed on an expansion of carapace, a wide cervical incision, and a deep postcervical incision (see Audo et al. 2014c). However, it presents characters diagnostic of Polychelidae: (1) the frontal margin is straight, (2) the frontal margin is placed posteriorly to anterolateral margin 
anterior angle, (3) the ocular incision is very small, (4) the ocular incision outer "angle" is distinct from anterolateral margin most anterior point (in Polychelidae these points are more angular and can be called "angle", here, the margin is rounded), (5) the cervical and postcervical incisions are shallow, (6) the posterolateral angle does not extend along the first pleonite, (7) the second pleonite tergopleuron covers first pleonite tergopleuron, and (8) the uropodal exopod is in one part, that is, without diaeresis. For these reasons, we propose to ascribe Woodwardicheles to Polychelidae.

Within Polychelidae, Woodwardicheles nov. gen. is distinguished from other genera by its carapace pyriform in outline in dorsal view. It is distinguished from all other genera except Cardus Galil, 2000 and Tauricheles nov. gen. by its cervical groove curving near median line (straight in other Polychelidae except Cardus and Tauricheles). It differs from all genera by its smooth frontal margin without rostral spines (with rostral spines in other Polychelidae, except Hellerocaris, unknown in Antarcticheles and Tauricheles). It is also distinguished from all genera but Hellerocaris by its branchial carina which anterior and posterior portions (on each side of cervical groove) are aligned (anterior portion nearer median line in other Polychelidae).

Woodwardicheles neocomiensis (Woodward, 1881) nov. comb. (Figs 4A-D, E)

1881 Eryon neocomiensis Woodward: 530-533, pl. 14, fig. 1.

1911 Eryon neocomiensis Woodward; Woodward 1911: 307.

1924 Eryon neocomiensis Woodward; Balss: 175. 
1925 Eryon neocomiensis Woodward; Van Straelen: 442.

1929 Eryon neocomiensis Woodward; Glaessner: 166.

1930 Eryon neocomiensis Woodward; Chernyshev: 376.

1944 Eryon neocomiensis Woodward; Roger: 193.

1968 Eryon neocomiensis Woodward; Pinna: 106.

2006 ?Eryon neocomiensis Woodward; Garassino \& Schweigert: 30.

2010 Eryon neocomiensis Woodward; Schweitzer et al.: 43.

2012 Eryon neocomiensis Woodward; Garassino et al.: 53.

2014c Eryon neocomiensis Woodward; Audo et al.: 495.

Type material. Holotype by monotypy: SNSB-BSPG AS I 994 (Figs 4A-C).

Type locality. Dolni Líštná (Carpathians, Czech Republic: Woodward 1881). The precise locality in vicinity of this town is unknown.

Type age. Middle Early Valanginian (= V. dolioliformis Subzone of the $N$. neocomiensiformis Zone of the Lower Valanginian) (this study).

Distribution. Only known in the type locality.

\section{Description.}

Outlines of carapace. Dorsoventrally flattened carapace, pyriform in outline in dorsal view, wider in its anterior half; smooth and straight frontal margin; frontal margin placed slightly posteriorly to anterior angle of anterolateral margin; anterolateral angle (inner angle of ocular incision) forming a small spine; very small, U-shaped ocular incision, with a rounded outer 
border; outer border "angle” of ocular incision distinct from the most anterior point of lateral margin; lateral margin with small spines, cut by cervical and postcervical incisions; very rounded anterolateral margin; very small cervical incision, only slightly deeper than postcervical incision; mediolateral margin rather straight; straight posterolateral margin, extending almost obliquely compared to median line; short posterolateral angle, not extending along the first pleonite; posterior margin slightly curved, wider than frontal margin.

Carapace grooves and carinae. Deep cervical groove, slightly oblique, extending from cervical incision to median line, curving slightly posteriorly near median line, cutting deeply median line; deep postcervical groove extending from postcervical incision toward median line, curving slightly forward near median line, not cutting median line; gastro-orbital groove extending obliquely from cervical groove toward median line, not reaching median line; branchiocardiac groove extending from the intersection of branchial carina and postcervical groove toward the rear of carapace, curving toward median line posteriorly, not cutting median line; branchiocardiac groove with a parallel carina; raised postrostral carina not reaching frontal margin, separated from postcervical carina by cervical groove; raised postcervical carina; postorbital carina extending from postorbital carina to merge with branchial carina; branchial carina straight, curving only slightly inward near cervical and postcervical grooves.

Pleon and telson. Pleon and telson combined longer than carapace; carapace two time wider than pleon; pleonite 1 shorter than others; subrectangular pleonites 2 to 5 terga, with two transverse grooves and an axial carina cutting posterior transverse groove; pleonite 6 tergum similar to others, with subtrapezoidal dorsal portion; tergopleura of pleonites 1 to 6 poorly preserved; long subtriangular telson, strengthened by a pair of longitudinal carina. 
Eyes and cephalic appendages. Eyes not preserved; antennula with at least one slender flagellum, poorly preserved; antenna with a wide basipod carrying (1) an ovoid scaphocerite (exopod) with a margin fringed with small curved spines, (2) an endopod with two subcylindrical podomeres carrying a flagellum of unknown length (endopod; distal portion not preserved).

Thoracic appendages. Large, chelate first pereiopod; first pereiopod with dactyl and pollex (fixed finger) slightly curved distally; palm (part of propodus not including pollex) with curved margins; very short subtriangular carpus.

Pleonal appendages. Uropod with stocky basipodite carrying petaloid endopod and exopod, both shorter than telson and strengthened by a median longitudinal carina.

Ornamentation. Small tubercles scattered on carapace.

\section{Discussion}

\section{Woodwardicheles, Tauricheles and their palaeoenvironments}

The reduced ocular incision of Woodwardicheles neocomiensis, its ascription to Polychelidae and modern aspect (see also below) are good evidence that it was probably, as extant species, adapted to deep water environments. This suggests a relatively deep bathymetry of the Silesian Basin during the early Valanginian time. This evidence alone would not be enough, but it confirms what geological and micropalaeontological studies results: the latest palaeontological (palynological) investigations of quantitative composition of the Early Cretaceous dinoflagellate cyst assemblages of the Silesian Basin indicate of inner to outer neritic palaeoenvironments with maximum depth calculated as few hundred meters (Skupien et al. 2013) contrary to bathyal depth previously suggested (Uchman et al. 2006), which was 
interpreted by benthic, primitive agglutinated foraminiferal associations in these units as well (upper to middle bathyal environment) (Geroch 1966, Szydło 1977, 2005).

Besides, the holotype of $W$. neocomensis is also important: such type of sedimentary basins usually have practically no autochthonous benthic fauna. W. neocomiensis is one of the rare macrofossil of autochthonous benthic animal to provide an idea of the depth of sedimentation of these flysch-type deposits.

The palaeoenvironment of Tauricheles crymensis is less well-constrained. However, expected for the preservation within a sideritic concretion and the age, the depositional settings of both species are surprisingly similar.

\section{Significance within the evolutionary history of polychelidans}

Tauricheles crymensis is the oldest representative of the Polychelidae known today. It attests of the antiquity of this family which diverged from other Polychelida at least at the ToarcianAalenian boundary. Possibly more importantly, its small ocular incisions could imply that it had small or reduced eyes, as modern Polychelidae do.

The second oldest recognized Polychelidae is the Callovian Hellerocaris falloti (Van Straelen, 1923) which possessed an unusual morphology, and possibly lived in a deep water palaeoenvironment (Charbonnier 2009, Charbonnier et al. 2010, Audo et al. 2014c, Charbonnier et al. 2014). The more recent Antarcticheles antarcticus (KimmeridgianTithonian) also resemble closely to modern polychelids, but surprisingly had rather large ocular incisions, which suggests it possessed an eye with a developed visual surface. The visual surface is always reduced in extant species (Galil 2000), but is often developed in fossil species (Spence Bate 1888, Schweigert \& Dietl 1999, Audo et al. 2014b, 2014c, Audo 2016, Audo et al. 2016). Finally, Haug et al. (2015) described, in the Late Cretaceous of Lebanon, crustaceans they interpret as polychelidan larvae bearing eyes with well-preserved visual 
surface. However, as explained above, the interpretation of these Late Cretaceous fossils is currently challenged.

Woodwardicheles neocomiensis has a very modern aspect: its ocular incisions are extremely small (Figs 4A, 4E), even smaller than those of Tauricheles crymensis (Fig. 2C, 2D). Woodwardicheles neocomiensis also has an ocular incision which does not lie along the lateral margin (outer angle of ocular incision and anterior angle of anterolateral margin separated). This disposition is also closer to that of extant species and Antarcticheles antarcticus (which has a large ocular incision) than to that of other fossil polychelidans. This smaller ocular incision is undoubtedly linked to a reduction of the visual capacities of W. neocomiensis compared to that of most other polychelidans with well-developed visual surfaces (Audo et al. 2016). These characteristics are also correlated to evidences for a relatively deep palaeoenvironment. Ahyong (2009) stated that the polychelid-like form was well established in Late Jurassic (referring to Antarcticheles antarcticus). Our redescription of Tauricheles crymensis shows that this polychelid habitus was in fact established much earlier, in Toarcian-Aalenian. Ahyong did not consider the species herein reinvestigated, as no up-todate reconstruction was available at the time. Based upon fossil polychelidans mostly from the Late Jurassic of Germany (Eryon cuvieri, Cycleryon propinquus, Knebelia bilobata and Palaeopolycheles longipes), Ahyong (2009) considered that there was a trend to live in deeper water from Eryonidae to Coleiidae and finally to Polychelidae. The reinvestigations of Tauricheles and Woodwardicheles suggest that the shift to deeper water might be older than previously considered, and if a shift to deep water existed in Coleiidae, it might be unrelated to that of Polychelidae. Indeed, Polychelidae already display a reduced ocular incision in the Toarcian-Aalenian, while the Coleiidae studied by Ahyong (2009), Palaeopolycheles longipes, dates from the Kimmeridgian (Dietl et al. 1998, Schweigert 2007b). 
Even if we take into account the fact that other species of polychelidans have not yet been identified as Polychelidae, we see that the fossil record of this family is rather discontinuous. Nevertheless, the fossil record of Polychelidae suggests that we should be extremely careful with the interpretation of trends in the evolutionary history of polychelidan lobsters, as we only have access to a highly biased sample of their past diversity.

\section{Conclusion}

1) The evolutionary history of Polychelidae, the family which includes all extant species is probably much older than previously envisioned.

2) The shift from shallow water to deep water is probably not observable based upon the currently known fossil record, as T. crymensis is older than most shallow water polychelidans (mostly Late Jurassic).

3) Both specimens are probably rare cases of autochthonous or parautochthonous preservation is similar turbitic environments.

4) W. neocomiensis is one of the rare benthic macrofossils in the Silesian Basin.

\section{Acknowledgments}

We are pleased to acknowledge the precious help of the curators Iraida Starodubtseva (GGM, Moscow, Russia), Mike Reich and Martin Nose (SNSB-BSPG, Munich, Germany), Günter Schweigert (SMNS, Stuttgart, Germany) and Claudia J. del Rio (National Scientific and Technical Research Council, Buenos Aires, Argentina). We also thank Maciej Borowiec (Polish Geological Institute - National Research Institute, Kraków, Poland) for drawings of figures 3 \& 6, Bernard Bataille (MNHN, Paris, France) for his helped with Russian translations Zdenek Vašíček (Academy of Sciences of the Czech Republic, Ostrava), Piotr Nescieruk and Wojciech Ryłko (Polish Geological Institute - National Research Institute, 
Kraków, Poland) for discussion on the Carpathian geology and Ferran Palero (Centre

d'Estudis Avançats de Blanes, Blanes, Spain) for the discussion about the interpretation of the Cenomanian “eryoneicus-like larvae”. Finally, we are indebted to our two reviewers, Shane T. Ahyong and Alessandro Garassino for their careful correction our manuscript and some insightful comments.

\section{References}

Aguirre-Urreta, M. B., Buatois, L. A., Chernoglasov G. C. B. \& Medina F. A. 1990. First Polychelidae (Crustacea, Palinura) from the Jurassic of Antarctica. Antarctic Science, 2(2), 157-162.

Ahyong, S. T. 2009. The Polychelidan Lobster: Phylogeny and Systematics (Polychelida : Polychelidae). Pp. 369-396 in J. W. Martin, K. A. Crandall \& D. L Felder (eds) Decapod Crustacean Phylogenetics. Crustacean Issues, Volume 18. Boca Raton, London, New York, CRC Press, Taylor \& Francis Group.

Ahyong, S.T. 2012. Polychelid lobsters (Decapoda: Polychelida: Polychelidae) collected by the CIDARIS expeditions off Central Queensland, with a summary of Australian and New Zealand distributions. Memoirs of the Queensland Museum - Nature, 56(1), 1-7.

Ahyong, S. T. \& Brown, D. E. 2002. New species and new records of Polychelidae from Australia (Crustacea: Decapoda). The Raffles Bulletin of Zoology, 50(1), 53-79.

Ahyong, S. T. \& Chan, T.-Y. 2008. Polychelidae from the Bohol and Sulu seas collected by PANGLAO 2005 (Crustacea: Decapoda: Polychelidae). The Raffles Bulletin of Zoology supplement, 19, 63-70.

Ahyong, S. T. \& Galil, B. S. 2006. Polychelidae from the southern and western Pacific (Decapoda, Polychelida). Zoosystema, 28 (3), 757-767. 
Artüz, M. L., Kubanç, C. \& Kubanç, S. N. 2014. Stereomastis artuzi sp. nov., a new species of Polychelidae (Decapoda, Polychelida) described from the sea of Marmara, Turkey. Crustaceana, 87(10), 1243-1257.

Audo, D. 2016. Tonneleryon, a new gregarious polychelidan lobster from the early Toarcian Posidonia Shale of Holzmaden (Germany). Neues Jahrbuch für Geologie und Paläontologie Abhandlungen, 280 (3), 285-298.

Audo, D., Charbonnier, S., Schweigert, G. \& Saint Martin, J.-P. 2014a. New eryonid crustaceans from the Late Jurassic Lagerstätten of Cerin (France), Canjuers (France), Wattendorf (Germany) and Zandt (Germany). Journal of Systematic Palaeontology, 12(4), 459-479.

Audo, D., Schweigert, G., Haug, J. T., Haug, C., Saint Martin, J.-P. \& Charbonnier, S. 2014b. Diversity and palaeoecology of the enigmatic genus Knebelia (Eucrustacea, Decapoda, Eryonidae) from Upper Jurassic plattenkalks in southern Germany. Palaeontology, 57(2), 397-416.

Audo, D., Schweigert, G., Saint Martin, J.-P. \& Charbonnier S. 2014c. High biodiversity in Polychelida crustaceans from the Jurassic La Voulte-sur-Rhône Lagerstätte. Geodiversitas, 36(4), 489-525.

Audo, D., Haug, J. T., Haug, C., Charbonnier, S., Schweigert, G., Müller, C. H. G. \& Harzsch, S. 2016. On the sighted ancestry of blindness - exceptionally preserved eyes of Mesozoic polychelidan lobsters. Zoological Letters, 2(13), 120. https://dx.doi.org/10.1186/s40851-016-0049-0 Audo, D., Schweigert, G., Charbonnier, S. \& Haug., J. T. accepted. Systematic revision and palaeobiology of Rosenfeldia triasica and Rogeryon oppeli nov. gen., nov. comb. (Eucrustacea, Polychelida). European Journal of Taxonomy. 
Audo, D., Williams, M., Charbonnier, S. \& Schweigert, G. 2017. Gabaleryon, a new genus of widespread early Toarcian polychelidan lobsters. Journal of Systematic Palaeontology 15(3), 205-222.

Bachmayer, F. 1947. Die Crustaceen aus dem Ernstbrunner Kalk der Jura-Klippenzone zwischen Donau und Thaya. Jahrbuch der Geologischen Bundesanstalt, 90, 35-43.

Bachmayer, F. 1959. Neue Crustaceen aus dem Jura von Stramberg (CSR). Sitzungsberichte der Österreichischen Akademie der Wissenschaften, mathematisch-naturwissnschaftliche Klasse, Abteilung I, 168, 937-944.

Balss, H. 1924. Studien an fossilen Decapoden II. Paläontologische Zeitschrift, 6(2), 174184.

Baraboshkin, E. J. \& Mikhailova, I. A. 2000. New and poorly known Valanginian ammonites from South-West Crimea. Bulletin de l'Institut Royal des Sciences Naturelles de Belgiques, Sciences de la Terre 70, 89-120.

Bengtson, S. 2000. Teasing fossils out of shales with cameras and computers. Palaeontologia Electronica 3 (Art. 4), 1-14.

Bernard, F. 1953. Decapoda Eryonidae (Eryoneicus et Willemoesia). Dana-Report 37, 1-93.

Bezerra, L. E. A. \& Bezerra Ribeiro, F. 2015. Primitive decapods from the deep sea: first record of blind lobsters (Crustacea: Decapoda: Polychelidae) in northeastern Brazil. Nauplius, 23(2), 125-131.

Bishop, G. A. 1986. Taphonomy of the North American Decapods. Journal of Crustacean Biology 6(3), 326-355.

Boorová, D., Skupien, P. \& Vašíček, Z. 2004 Biostratigraphy of the Lower Cretaceous limestones of the Godula facies of the Silesian Unit, Outer Western Carpathians. Bulletin of Geosciences, 79(2), 121-131. 


\section{Bravi, S., Garassino, A., Bartiromo, A., Audo, D., Charbonnier, S., Schweigert, G.,}

Thévenard, F. \& Longobardi, C. 2014. Middle Jurassic Monte Fallano Plattenkalk

(Campania, southern Italy): first report on terrestrial plants, decapod crustaceans and fishes.

Neues Jahrbuch für Geologie und Paläontologie Abhandlungen 272(1), 79-107.

Bujtor, L. 2013. Valanginian perisphinctid ammonites from the Kisújbánya Basin (Eastern Mecsek Mts., Hungary). Cretaceous Research 41, 1-16.

Cartes J. E. \& Abelló P. 1992. Comparative feeding habits of polychelid lobsters in the Western Mediterranean deep-sea communities. Marine Ecology Progress Series, 84(2), 139150.

Chan, T., Poore, G. \& Türkay, M. 2011. Polychelidae Wood-Mason, 1875. Accessed through: World Register of Marine Species at http://www.marinespecies.org/aphia.php?p=taxdetails\&id=106793 on 2017-03-01.

Chang, S.-C., Ahyong, S. T. \& Chan, T.-Y. 2013. New Records of Deep-Sea Blind Lobsters (Crustacea: Decapoda: Polychelidae) from Taiwan. Journal of Marine Science and Technology, 21 suppl., 8-14.

Charbonnier, S. 2009. Le Lagerstätte de La Voulte : un environnement bathyal au Jurassique. Mémoires du Muséum national d'Histoire naturelle, 199, 1-272.

Charbonnier, S., Audo, D., Caze, B. \& Biot V. 2014. The La Voulte-sur-Rhône Lagerstätte (Middle Jurassic, France). Comptes Rendus Palevol, 13 (5), 369-381.

Charbonnier, S., Garassino, A., Schweigert, G. \& Simpson, M. 2013. A worldwide review of fossil and extant glypheid and litogastrid lobsters (Crustacea, Decapoda, Glypheoidea). Mémoires du Muséum National d’Histoire Naturelle, 205, 1-304.

Charbonnier, S., Vannier, J., Hantzpergue, P. \& Gaillard C. 2010. Ecological significance of the arthropod fauna from the Jurassic (Callovian) La Voulte Lagerstätte. Acta Palaeontologica Polonica, 55(1), 111-132. 
Chernyshev, B. 1930. New Eryonidae from Vilui River. Izvestija Vsesojuznoe

Geologorazuedochinoe Upravlenie, 49, 375-384 [in Russian].

Company, M. \& Tavera, J. M. 1982. Los ammonites del transito Berriasense-Valanginiense en la region de Cehegin (Prov. De Murcia, SE de España). Cuadernos Geologia Ibérica, 8, 651-664.

Company, M. \& Tavera, J. M., 2013. Lower Valanginian ammonite biostratigraphy in the Betic Cordillera (southeastern Spain): new data. Pp. 118-119 in: 9th International Symposium on the Cretaceous System, Ankara (Turkey). Abstract Book, Middle East Technical University, Ankara.

Company, M. \& Tavera, J. M. 2015. Lower Valanginian ammonites biostratigraphy in the Subbetic Domain (Betic Cordillera, southeastern Spain). Carnets de Géologie, 15(8), 71-88.

Dall'Occo, P. L. \& Tavares, M. 2004. New and additional records of deep-water blind lobsters from Brazil (Decapoda, Polychelidae). Nauplius 12(2), 143-149.

Desmarest, A.-G. 1817. Crustacés fossiles. Pp. 495-519 in Société de Naturalistes et d'Agriculteurs (Eds), Nouveau Dictionnaire d'Histoire naturelle, appliquée aux Arts, à l'Agriculture, à l'Économie rurale et domestique, à la Médecine, etc. 7. Déterville, Paris. Dietl, G., Schweigert, G., Franz, M. \& Geyer, M. 1998. Profile des Nusplinger Plattenkalks (Oberjura, Ober-Kimmeridgium, Südwestdeutschland). Stuttgarter Beiträge zur Naturkunde $B, 265,1-37$.

Doyle, P. 1991. Belemnites from the Lower Jurassic of East Greenland and their biostratigraphical and biogeographical significance. Bulletin of the Geological Society of Denmark, 39(2), 123-141.

Eliáš, M., Skupien, P. \& Vašíček, Z. 2003. A proposal for the modification of the lithostratigraphical division of the lower part of the Silesian unit in the Czech area (outer western Carpathians). Sborník Vědeckých Prací Vysoké Školy bán̆ské - Technické Univerzity 
Ostrava, Řada Hornicko-Geologická, Monografie, 8(49), 7-13. [In Czech with English abstract]

Ettachfini, M. 2004. Les ammonites néocomiennes dans l'Atlas atlantique (Maroc) biostratigraphie, paléontologie, paléobiogéographie et paleoecologie. Strata Série 2, 43, 1225.

Faraoni, P., Flore, D., Marini, A., Pallini, G. \& Pezzoni, N. 1997. Valanginian and early Hauterivian ammonite successions in the Mt Catria group (Central Apennines) and in the Lessini Mts (Southern Alps), Italy. Palaeopelagos, 7, 59-100.

Farias N. E., Ocampo, E. H. \& Luppi, T. A. 2015. On the presence of the deep-sea blind lobster Stereomastis suhmi (Decapoda: Polychelidae) in Southwestern Atlantic waters and its circum-Antarctic distribution. New Zealand Journal of Zoology, 42(2), 119-125.

Feldmann, R. M., Schweitzer, C. E., Karasawa, H., Schweigert, G. \& Garassino A. 2013. Part R, Revised, Volume 1, Chapter 8G: Systematic descriptions: Infraorder Polychelida. Treatise Online, 60, 1-10, 6 figs.

Firth, R. M. \& Pequegnat, W. E. 1971. Deep-sea lobsters of the families Polychelidae and Nephropidae (Crustacea, Decapoda) in the Gulf of Mexico and Caribbean Sea. Texas A\&M University, Department of Oceanography, 1-106.

Förster, R. 1967. Die reptanten Dekapoden der Trias. Neues Jahrbuch für Geologie und Paläontologie Abhandlungen, 128(2), 136-194.

Fözy, I., Janssen, N. M. M., Price, G. D., Knauer, J. \& Pálfy, J. 2010. Integrated isotope and biostratigraphy of a Lower Cretaceous section from the Bakony Mountains (Transdanubian Range, Hungary): A new Tethyan record of the Weissert event. Cretaceous Research, 31(6), 525-545.

Fraaije, R. H. B., Bakel, B. W. M., van, Jagt, J. W. M. \& Skupien, P. 2013. First record of paguroid anomurans (Crustacea) from the Tithonian-lower Berriasian of Štramberk, Moravia 
(Czech Republic). Neues Jahrbuch für Geologie und Paläontologie Abhandlungen, 269(3), 251-259.

Galil, B. S. 2000. Crustacea Decapoda: review of the genera and species of the family Polychelidae Wood-Mason, 1874. In: Crosnier A. (Ed.) Résultats des campagnes MUSORSTOM, Volume 21. Mémoires du Muséum national d'Histoire naturelle, 184, 285387.

Garassino, A., Pini, G. A. \& Pasini, G. 2012. First report of a polychelid lobster (Crustacea: Decapoda: Coleiidae) from the Early Cretaceous of Italy. Neues Jahrbuch für Geologie und Paläontologie Abhandlungen, 263(1), 47-55.

Garassino, A. \& Schweigert, G. 2006. The Upper Jurassic Solnhofen decapod crustacean fauna: review of the types from old descriptions. Part I. Infraorders Astacidea, Thalassinidea, and Palinura. Memorie della Società italiana di Scienze naturali e del Museo civico di Storia naturale di Milano, 34, 1-64.

Geroch, S. 1966. Lower Cretaceous small Foraminifera of the Silesian Series, Polish Carpathians. Annales Societatis Geologorum Poloniae, 36(4), 413-480. [in Polish with English summary].

Glaessner, M. F. 1929. Crustacea Decapoda. Pp. 1-464 in J. F. Pompeckj (Ed.) Fossilium Catalogus I: Animalia, 41, W. Junk, Berlin.

Glaessner, M. F. 1969. Decapoda. Pp. 399-533 in R. C. Moore (Ed.) Treatise on Invertebrate Paleontology, Part R, Arthropoda, 4 (2).

Golonka, J. Gahagan, L., Krobicki, M., Marko, F., Oszczypko, N. \& Ślączka, A. 2006. Plate Tectonic Evolution and Paleogeography of the Circum-Carpathian Region. Pp. 11-46 In: J. Golonka \& F. Picha (Eds.) The Carpathians and their foreland: Geology and hydrocarbon resources. American Association of Petroleum Geologists, Memoir, 84. 
Golonka, J., Vašíček, Z., Skupien, P., Waśkowska-Oliwa, A., Krobicki, M., Cieszkowski, M., Ślączka, A. \& Słomka, T. 2008. Litostratygrafia osadów górnej jury i dolnej kredy zachodniej części Karpat zewnętrznych (propozycja do dyskusji) (Lithostratigraphy of the Upper Jurassic and Lower Cretaceous deposits of the western part of the Outer Carpathians (discussion proposition)). Pp. 9-31 in M. Krobicki (Ed.), Utwory przełomu jury i kredy w zachodnich Karpatach fliszowych polsko-czeskiego pogranicza, Jurassica VII, 27-29.09.2008 - Żywiec/Štramberk. Kwartalnik AGH Geologia, 34(3/1). [in Polish with English summary] Gore, R. H. 1984. Abyssal Lobsters, Genus Willemoesia (Palinura, Polychelidae), from the Venezuela Basin, Caribbean Sea. Proceedings of the Academy of Natural Sciences of Philadelphia, 135, 1-11.

Grădinaru, M., Lazar, I., Bucur, I. I., Grădinaru, E., Săsăran, E., Ducea, M. N. \& Andrăşanu, A. 2016. The Valanginian history of the eastern part of the Getic Carbonate Platform (Southern Carpathians, Romania): Evidence for emergence and drowning of the platform. Cretaceous Research, 66, 11-42.

Halásová, E., Vašíček, Z., Jansa, L., Reháková, D. \& Skupien, P. 2012. Lower Cretaceous succession and biostratigraphy near overthrust plane of Silesian Nappe (Ostravice River Channel, Outer Western Carpathians, Czech Republic). Bulletin of Geosciences, 87, 2: 383406.

Harding, I. C., Smith, G. A., Riding, J. B. \& Wimbledon, W. A. P. 2011. Inter-regional correlation of Jurassic/Cretaceous boundary strata based on the Tithonian-Valanginian dinofagellate cyst biostratigraphy of the Volga Basin, western Russia. Review of Palaeobotany and Palynology, 167, 82-116.

Haug, J. T., Audo, D., Charbonnier, S., Haug, C., Abi Saad, P. \& Petit, G. 2015. Unique occurrence of polychelidan lobster larvae in the fossil record and its evolutionary implications. Gondwana Research, 28(2), 869-874. 
Haug, C, Haug, J. T., Waloszek, D., Maas, A., Frattigiani, R. \& Liebau, S. 2009. New methods to document fossil from lithographic limestones of southern Germany and Lebanon. Palaeontologia Electronica, 12(3), 6T, 1-12.

Haug, C., Mayer, G., Kutschera, V., Waloszek, D., Maas, A. \& Haug, J. T., 2011. Imaging and documentating gammarideans. International Journal of Zoology, 2011, 380829, 1-9. http://dx.doi.org/10.1155/2011/380829

Heller, C. 1862. Beiträge zur näheren Kenntniss der Macrouren. Sitzungsberichte der Kaiserlichen Akademie der Wissenschaften in Wien, mathematisch-physikalische Klasse, 45(1), 389-426.

Heller, C. 1863. Die Crustaceen des südlichen Europa. Crustacea Podophthalmia. Wilhelm Braümüller, Wien, i-xi, 1-328, pls 1-10.

Hoedemaeker, P. J., Reboulet, S., (reporters), Aguirre-Urreta, M. B., Alsen, P., Aoutem, M., Atrops, F., Barragan, R., Company, M., González Arreola, C., Klein, J., Lukeneder, A., Ploch, I., Raisossadat, N., Rawson, P. F., Ropolo, P., Vašíček, Z., Vermeulen, J. \& Wippich M. G. E. 2003. Report on the 1st International Workshop of the IUGS Lower Cretaceous Ammonite Working Group, the “Kilian Group” (Lyon, 11 July 2002). Cretaceous Research, 24(1), 89-94, and erratum (p. 805).

Hohenegger, L. 1852. Geognostische Skizze der Nordkarpathen von Schlesien und den nächsten Angränzungen (nach dem gegenwärtigen Standpuncte meiner Erfahrungen). Jahrbuch der Kaiserlich-Königlichen Geologischen Reichsanstalt, 3, 135-148, pl. 1. ICZN 1999. International Code of Zoological Nomenclature. International Trust for Zoological Nomenclature. The Natural Museum, London, v-xxix, 1-306.

Jauvion, C., Audo, D., Charbonnier, S. \& Vannier, J. 2016. Virtual dissection and lifestyle of a 165-million-year-old female polychelidan lobster. Arthropod Structure and Development, 45(2), 122-132. 
Jones, D.O.B., Gates, A.R., Curry, R.A., Thomson, M., Pile, A. \& Benfield, M. (Eds.), 2009. SERPENT project. Accessed through: Media database archive at http://archive.serpentproject.com/1734/ on 2017-03-15.

Karasawa, H., Takahashi F., Doi, E. \& Ishida, H. 2003. First notice of the family Coleiidae Van Straelen (Crustacea: Decapoda: Eryonoidea) from the upper Triassic of Japan.

Paleontological Research, 7(4), 357-362.

Kołodziej, B. 2015a. Geological context and age of the Štramberk-type limestones from the Polish Outer Carpathians: an overview. Neues Jahrbuch für Geologie und Paläontologie Abhandlungen, 276(2), 173-179.

Kołodziej, B. 2015b. Corals of the Štramberk-type limestones from Poland: Taxonomic and palaeoecological aspects. Neues Jahrbuch für Geologie und Paläontologie Abhandlungen, 276(2), 181-199.

Krobicki, M. \& Fraaije, R. H. B. In press. A new spiny lobster from the Upper Jurassic Štramberk-type limestones of Inwałd, Andrychów Klippen, southern Poland. Bullutin de la Société géologique de France, 187.

Krobicki, M. \& Zatoń, M. 2008. Middle and Late Jurassic roots of brachyuran crabs: Palaeoenvironmental distribution during their early evolution. Palaeogeography, Palaeoclimatology, Palaeoecology, 263(1-2), 30-43.

Krobicki, M. \& Zatoń, M. 2016. A new homolodromioid crab (Brachyura: Dromiacea: Tanidromitidae) from the Bajocian of Central Poland and a review of the stratigraphical distribution and paleoenvironments of the known Middle Jurassic homolodromioids. Journal of Crustacean Biology, 36(5), 695-715.

Lagardère J.-P. 1973. Distribution des Décapodes dans le sud du Golfe de Gascogne. Revue des Travaux de l'Institut des Pêches Maritimes, 37(1), 77-95. 
Levitski, E. C. 1974. Fossil decapod crustaceans from the vicinity of the Bakhchisarai (the Crimea). Byulletin Moskovskogo Obshchestva Ispytatelei Prirody Otdel Geologicheskii, 49(6), 101-119. [in Russian, with English translation].

Lexa, J., Bezák, V., Elečko, M., Mello, P., Polák, M., Potfaj, M. \& Vozár, J. (eds). 2000. Geological Map of Western Carpathians and Adjacent Areas 1:500 000. Ministry of the Environment of Slovak Republic, Geological Survey of Slovak Republic, Bratislava.

Malik, K. \& Olszewska, B. 1984. Studium sedymentologiczne i mikropaleontologiczne warstw grodziskich w profilu Żegociny (Karpaty fliszowe) (Sedimentological and micropaleontological study of the Grodziszcze Beds at Żegocina (Flysch Carpathians)). Annales Societatis Geologorum Poloniae, 54(3/4), 293-334. [in Polish with English summary]

Mazarovich O. A. \& Mileev V. S. 1989. Guidebook on the Geological Structure of the Kacha Uplift in the Mountain of Crimea (Mesozoic Stratigraphy). Moscow State University, Moscow, 168 pp. [in Russian]

Menčík, E., Adamová, M., Dvořák, J., Dudek, A., Jetel, J., Jurková, A. \& Hanzlíková, E. 1983. Geologie Moravskoslezských Beskyd a Podbeskydské pahorkatiny. Geology of the Moravskoslezské Beskydy Mts and the Podbeskydská pahorkatina Upland. Ustredni Ústav Geologicky NČSAV, Praha, 304 pp. [in Czech with English summary].

Moericke, W. 1889. Die Crustaceen der Stramberger Schichten. Palaeontographica, (Suppl.) 2, 43-72.

Müller, P., Krobicki, M., Wehner, G. 2000 Jurassic and Cretaceous primitive crabs of the family Prosopidae (Decapoda: Brachyura) - Their taxonomy, ecology and biogeography. Annales Societatis Geologorum Poloniae, 70, $49-79$.

Muratov M. V. 1960. Short Essay of Geological Structure of Crimea Peninsula. GNTI, Moscow, 207 pp. [in Russian]. 
Muratov, M. V., Archipov, I. V. \& Uspenskaya, E. A. 1984. Structural evolution of the Crimea in comparison to the West Caucasus in the Eastern Balkans. Byulleten Moskovskogo Obshchestva Ispytateley Prirody, Otdeleniye Geologii, 59, 3-10. [in Russian with English summary]. http://dx.doi.org/10.1080/00206818409466646

Nikishin, A. M., Wanniert, M., Alekseev, A. S., Almendinger, A., Fokin, P. A., Garbullin, R. R., Khudoley, A. K., Kopaevich, L. F, Mityukov, A. V., Petrov, E. I. \& Rubtsova, E. V. 2015. Mesozoic to recent geological history of southern Crimea and Eastern Black Sea region. Geological Society, London, Special Publications, 428, 1-23.

Nikolov, T. G. 1977. On the ammonite genus Busnardoites Nikolov, 1966 (Berriasellidae, Lower Cretaceous). Geologica Balcanica 7(4), 107-118.

Oszczypko, N., Ślączka, A., Bubniak, I., Olszewska, B. \& Garecka, M. In press. The position and age of flysch deposits in the Crimean Mountains (Southern Ukraine). Geological Quarterly 61.

Patrulius, D. 1966. Les Décapodes du Tithonique inférieur de Woźniki (Carpates Polonaises Occidentales). Annales Societatis Geologorum Poloniae, 36, 495-517.

Petrova, S., Rabrenović, D., Lakova, I., Koleva-Rekalova, E., Ivanova, D., Metodiev, L. \& Malešević, N. 2012. Biostratigraphy and microfacies of the pelagic carbonates across the Jurassic/Cretaceous boundary in eastern Serbia (Stara Planina-Poreč Zone). Geologica Balcanica, 41(1-3), 53-76.

Picha, F., Stráník, Z. \& Krejčí, J. 2006. Geology and Hydrocarbon Resources of the Outer West Carpathians and their foreland, Czech Republic. Pp. 49-175 in J. Golonka \& F. Picha (Eds.), The Carpathians and their foreland: Geology and hydrocarbon resources: American Association of Petroleum Geologists, Memoir, 84, 49-175. 
Pinna, G. 1968. Gli Erionidei della nuova fauna sinemuriana a crostacei decapodi di Osteno in Lombardia. Atti della Società italiana di Scienze naturali e del Museo civico di Storia naturale in Milano, 107(2), 93-134.

Plotnick, R. E. 1986. Taphonomy of a modern shrimp: implications for the arthropod fossil record. Palaios, 1(3), 286-293.

Plotnick, R. E., Baumiller, T. \& Wetmore, K. 1988. Fossilization potential of the mud crab, Panopeus (Brachyura: Xanthidae) and temporal variability in crustacean taphonomy. Palaeogeography, Palaeoclimatology, Palaeoecology, 63(1-3), 27-43.

Rathbun, M. J. 1919. West Indian Tertiary Decapod Crustaceans. Pp. 157-184, pl. 1-9 in T. Wayland Vaughan (Ed.). Contributions to the geology and paleontology of the West Indies. Reboulet, S. 1996. L'evolution des ammonites du Valanginiene-Hauterivien inférieur du bassin vocontien et de la plate-forme provençal (Sud-Est de la France): relations avec la stratigraphie séquentielle et implications biostratigraphiques. Documents des Laboratoires de Géologie de Lyon, 137(1995), 371 pp.

Reboulet, S. \& Atrops, F. 1999. Comments and proposals about the Valanginiane Lower Hauterivian ammonite zonation of south-east France. Eclogae geologicae Helvetiae, 92, 183197.

Reboulet, S., Hoedemaeker, P. J., (reporters), Aguirre-Urreta, M. B., Alsen, P., Atrops, F., Baraboshkin, E. Y., Company, M., Delanoy, G.,Dutour, Y., Klein, J., Latil, J. L., Lukeneder, A., Mitta, V., Mourgues, F. A., Ploch, I., Raisossadat, N., Ropolo, P., Sandoval, J., Tavera, J. M., Vašíček, Z. \& Vermeulen, J. 2006. Report on the $2^{\text {nd }}$ international meeting of the IUGS lower Cretaceous ammonite working group, the "Kilian Group” (Neuchâtel, Switzerland, 8 September 2005). Cretaceous Research, 27, 712-715. Reboulet, S., Szives, O., Aguirre-Urreta, B., Barragán, R., Company, M., Idakieva, V., Ivanov, M., Kakabadze, M. V., Moreno-Bedmar, J. A., Sandoval, J., Baraboshkin E. J., 
Çağlar, M. K., Főzy, I., González-Arreola, C., Kenjo, S., Lukeneder, A., Raisossadat, S.

N., Rawson, P. F. \& Tavera, J. M. 2014. Report on the 5th International Meeting of the

IUGS Lower Cretaceous Ammonite Working Group, the Kilian Group (Ankara, Turkey, 31st August 2013). Cretaceous Research, 50, 126-137.

Remeš, M. 1895. Beiträge zur Kenntnis der Crustaceen der Stramberger Schichten. Bulletin of the International Academy of Science, Boheme, 2, 200-204.

Robins, C. M., Feldmann, R. M. \& Schweitzer, C. E. 2012. The oldest Munididae (Decapoda: Anomura: Galathoidea) from Ernstbrunn, Austria (Tithonian). Annalen des Naturhistorischen Museum in Wien, Serie A, 114, 289-300.

Robins, C. M., Feldmann, R. M. \& Schweitzer, C. E. 2013. Nine new genera and 24 new species of the Munidopsidae (Decapoda: Anomura: Galathoidea) from the Jurassic Ernstbrunn Limestone of Austria, and notes on fossil munidopsid classification. Annalen des Naturhistorischen Museum in Wien, Serie A, 115, 167-251.

Roger, J. 1944. Eryoneicus ? Sahel almae n. sp., crustacé décapode du Sénonien du Liban. Bulletin du Muséum national d’Histoire naturelle Paris, Série 2, 16(3), 191-194.

Santucci, R. 1933. Biologia del fondo a “'Scampi”' nel Mar Ligure. I. Polycheles typhlops Heller. Memorie Reale Comitato talassografico italiano, 199, 1-48.

Schäfer, W. 1951. Fossilizations-Bedingungen brachyuren Krebse. Abhandlungen der Senckenbergischen naturforschenden Gesellschaft, 485, 225-230.

Schweigert, G. 2007a. Preservation of decapod crustaceans in the Upper Jurassic lithographic limestones of southern Germany, Pp. 87-90in A. Garassino, R. M. Feldmann, G. Teryzzi (Eds), 3rd Symposium on Mesozoic and Cenozoic decapod crustaceans. Memorie della Società Italiana di Scienze Naturali e del Museo Civico di Storia Naturale di Milano, 35(2), 87-90. 
Schweigert, G. 2007b. Ammonite biostratigraphy as a tool for dating Upper Jurassic lithographic limestones from South Germany - first results and open questions. Neues Jahrbuch für Geologie und Paläontologie Abhandlungen, 245(1), 117-125.

Schweigert, G. \& Dietl, G. 1999. Neubeschreibung von 'Eryon longipes O. Fraas’ (Crustacea, Decapoda, Eryonidea) aus dem Nusplinger Plattenkalk (Ober-Kimmeridgium, Schwäbische Alb). Stuttgarter Beiträge zur Naturkunde, Serie B, 274, 1-19.

Schweigert, G. \& Herd K. J. 2010. Ein Vielscherer aus der Unterkreide. Fossilien 27(4), 212-217.

Schweitzer, C. E. \& Feldmann, R. M. 2009. New species of Longodromitidae Schweitzer and Feldmann, 2009, from the Ernstbrunn Formation, Late Jurassic (Tithonian), Austria. Annalen des Naturhistorischen Museum in Wien, Serie A 111, 207-224.

Schweitzer, C. E., Feldmann, R. M., Garassino, A., Karasawa, H. \& Schweigert, G. 2010. Systematic list of fossil decapod crustacean species. Crustaceana Monographs 10, 1222.

Skupien, P. 1999. Dinoflagellate cysts distribution of Albian-Cenomanian sections from the Outer Western Carpathians. Bulletin of Czech Geological Survey 74(1), 1-10.

Skupien, P. \& Smaržová, A. 2011. Palynological and geochemical response to environmental changes in the Lower Cretaceous in the OuterWestern Carpathians; a record from the Silesian unit, Czech Republic. Cretaceous Research, 32(4), 538-551.

Skupien, P. \& Vašíček, Z. 2002. Lower Cretaceous ammonite and dinocyst biostratigraphy and paleoenvironment of the Silesian basin (OuterWestern Carpathians). Geologica Carpathica, 53(3), 179-189.

Skupien, P., Smaržová, A. \& Měchová, L. 2013. Palaeoenvironmental change in the Early Cretaceous Silesian Basin of the Western Carpathians (NE Czech Republic) inferred from palynological data. Review of Palaeobotany and Palynology, 197, 143-151. 
Solov'ev, A. V. \& Rogov, M. A. 2010. First fission track dating of zircons from Mesozoic complexes of the Crimea. Stratigraphy and Geological Correlation, 18(3), 298-306.

Spence Bate, C. 1888. Report on the Crustacea Macrura collected by H.M.S. Challenger during the years 1873-1876. Pp. 1-942 in C. Wyville Thomson \& J. Murray (Eds) Report on the scientific results of the voyage of the H.M.S. Challenger during the years 1873-76 under the command of Captain Georges S. Nares R.N., F.R.S. and the late Captain Frank Tourle Thomson, R.N. Zoology, 24, Neill, Edinburgh.

Szydło, A. 1997. Biostratigraphical and paleoecological significance of small foraminiferal assemblages of the Silesian (Cieszyn) Unit, Polish Western Carpathians. Annales Societatis Geologorum Poloniae, 67, 345-354.

Szydło, A. 2005. Benthic foraminiferal morphogroups and taphonomy of the Cieszyn beds (Tithonian-Neocomian, Polish Outer Carpathians). Studia Geologica Polonica, 124, 199-214. Ţibuleac, P. 2012. New data on the Early Cretaceous between Gura Sadovei and Pojorâta (Rarău Syncline, Eastern Carpathians, Romania). Analele Stiintifice ale Universitatii “Al. I. Cuza” din Iasi Seria Geologie, 58(2) 35-52.

Uchman, A., Malata, E., Olszewska, B. \& Oszczypko, N. 2006. Palaeobathymetry of the outer Carpathian basins. Pp. 85-102 in N. Oszczypko, A. Uchman, E. Malata (Eds.), Palaeotectonic Evolution of the Outer Carpathian and Pieniny Klippen Belt Basins. Instytut Nauk Geologicznych Uniwersytetu Jagiellońskiego, Kraków.

Uhlig, V. 1902. Über die Cephalopodenfauna der teschener und Grodischter Schichten. Denkschriften der Kaiserlichen Akademie der Wissenschaften Wien, Mathematischnaturwissenschaftliche Classe, 72, 1-88.

Van Straelen, V. 1925. Contribution à l'étude des Crustacés décapodes de la période jurassique. Mémoires de la Classe des Sciences de l'Académie royale de Belgique 2e série, 7 , $1-462$. 
Vašíček, Z. 1975. Zur Revision der Ammoniten von den Oberen Těšín-Schichten (ValendisStufe). Sborník Geologických Věd, Paleontologie, 17, 71-107.

Vašíček, Z. 1995. Lower Cretaceous ammonite biostratigraphy in the Western Carpathians (the Czech and Slovak republics). Géologie Alpine, Mémoire hors série, 20, 169-189.

Vašíček, Z. 2010. Early Cretaceous ammonites from the Butkov Quarry (Manín Unit, Central Western Carpathians, Slovakia). Acta Geologica Polonica, 60(3), 393-415.

Vašíček, Z. \& Skupien, P. 2002. Notes on some rare Barremian/Aptian ancyloceratids from the Silesian Unit (Outer Western Carpathians, Czech Republic). Journal of Czech Geological Society, 47(1-2), 65-74.

Wills, M. A. 2001. How good is the fossil record of arthropods? An assessment using the stratigraphic congruence of cladograms. Geological Journal, 36, 187-210.

Wood-Mason, J. 1874. On Blind Crustaceans. Proceedings of the Asiatic Society of Bengal, 1874, $180-181$.

Woodward, H. 1866. Notes on the species of the genus Eryon Desmarest from the Lias and Oolite of England and Bavaria. Quarterly Journal of the Geological Society of London, 22, 494-502.

Woodward, H. 1877. Catalogue of British fossil crustacea, with their synonyms and the range in time of each genus and order. Taylor and Francis, London, 155 pp.

Woodward, H. 1881. Contribution to the study of fossil Crustacea. The Geological Magazine, new series Decade II, 8, 529-534.

Woodward, H. 1911. On a new species of Eryon from the Upper Lias, Dumbleton Hill. The Geological Magazine, new series Decade V, 8, 307-311.

Wyville Thompson, C. 1873a. Notes from the "Challenger” II. Nature, 8(185), 51-53.

Wyville Thompson, C. 1873b. Notes from the “Challenger” IV. Nature, 8(195), 246-249. 


\section{Żytko, K., Zając, R., Gucik, S., Ryłko, W., Oszczypko, N., Garlicka, I., Nemčok, J.,}

Eliáš, M., Menčík, E. \& Stránik, Z. 1989. Map of the tectonic elements of the Western Carpathians and their foreland. in D. Poprawa \& J. Nemčok, (Eds) Geological atlas of the Western Outer Carpathians and their foreland. Państwowy Instytut Geologiczny, Warszawa/GUDŠ Bratislava/Uug Praha.

\section{Figures captions}

\section{Figure 1}

Geological map of Crimean Mountains region (simplified from Mazarovich et al. 1989, Solov'ev \& Rogov 2010) with locality of Tauricheles crymensis nov. comb. (red dot).

\section{Figure 2}

Tauricheles nov. gen. and Palaeopolycheles Knebel, 1907. A-C, holotype of Tauricheles crymensis (Levitski, 1974) nov. comb. (GGM VI-165/1) from the Toarcian-Aalenian of Yaman ravine (Crimea), inner side of dorsal surface, white light (A), interpretative linedrawing (B), and detail of the ocular incision (C) with interpretative line-drawing (D); $\mathbf{E}$, well-preserved specimen of Palaeopolycheles longipes (Fraas, 1855) (SMNS 63833) from the Kimmeridgian of Nusplingen (Germany), inner side of dorsal surface in cross-polarized light; F-G, comparison sketches of the carapace outlines, grooves and carinae of Palaeopolycheles (F) and Tauricheles (G). Abbreviations: a, branchiocardiac groove; a2?; traces of antennae?; ap, carina parallel to branchiocardiac groove; ba, uropodal basipod; bc, branchial carina; c, postcervical groove; ci, postcervical incision; di, diaeresis; e1e, cervical groove; ei, cervical incision; en, uropodal endopod; ex, uropodal exopod; o, ocular incision; P1-P4, pereiopods 1 to 4; pla, posterolateral angle; s1-s6, pleonites 1 to 6; t, telson. Scale bars: $10 \mathrm{~mm}$. Photographs: Iraida Starodubtseva (A, C) and Denis Audo (D). 


\section{Figure 3}

Geological map of the vicinity of Dolní Lišstná where Woodwardicheles neocomiensis was discovered (after Żytko et al. 1989, Lexa et al. 2000, simplified).

\section{Figure 4}

Woodwardicheles nov. gen. and Eryon Desmarest, 1817. A-C, holotype of Woodwardicheles neocomiensis (Woodward, 1881) nov. comb. (SNSB-BSPG AS I 994), in dorsal view, composite image combining red channel of cross-polarized picture of part and counterpart (A), interpretative line-drawing (B) and counterpart in cross-polarized light (C). D, sketch of the carapace of Eryon cuvieri Desmarest, 1817, type species of Eryon. E, sketch of the carapace of Woodwardicheles neocomiensis Abbreviations: a, branchiocardiac groove; a1?, fragments of antennula; a2, antenna; ap, carina parallel to branchiocardiac groove; alc, anterolateral cervical spine; ba, uropodal basipod; bc, branchial carina; c, postcervical groove; ci, postcervical incision; d, gastro-orbital groove; di, diaeresis; e1e, cervical groove; ei, cervical incision; en, uropodal endopod; ex, uropodal exopod; o, ocular incision; P1, pereiopod 1; pc, postcervical carina; pla, posterolateral angle; pr, postrostral carina; s1-s6, pleonites 1 to 6; t, telson. Scale bars: 5 mm. Photographs: Joachim T. \& Carolin Haug.

\section{Figure 5}

Ripplemark-type (convolute) sedimentary structures of turbiditic origin, on three sides of Eryon neocomiensis holotype matrix, perpendicular to bedding. Scale bar: $1 \mathrm{~cm}$.

\section{Figure 6}

Upper Jurassic - Lower Cretaceous lithostratigraphy of the Carpathians (Silesian Nappe) (after Golonka et al. 2008, simplified) with position of examined specimen (black star). 

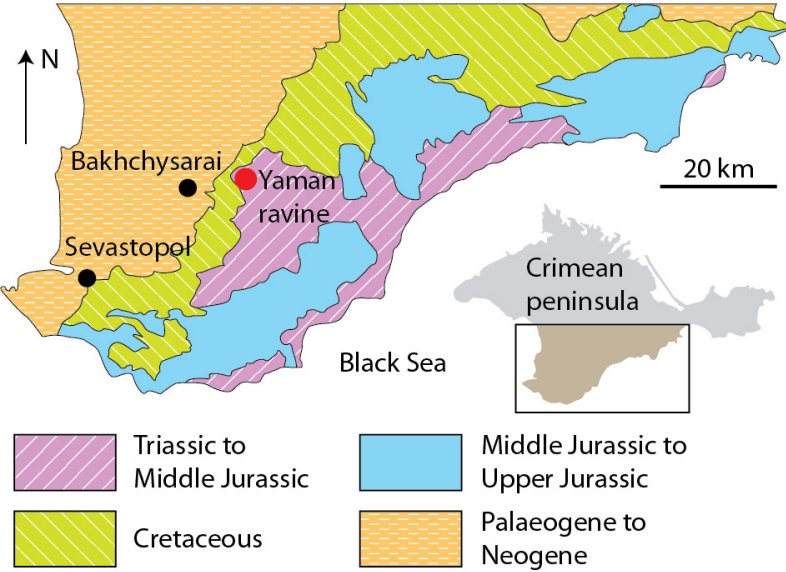

Triassic to Middle Jurassic

Cretaceous

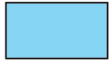

Middle Jurassic to Upper Jurassic

Palaeogene to Neogene 


\section{A}

B

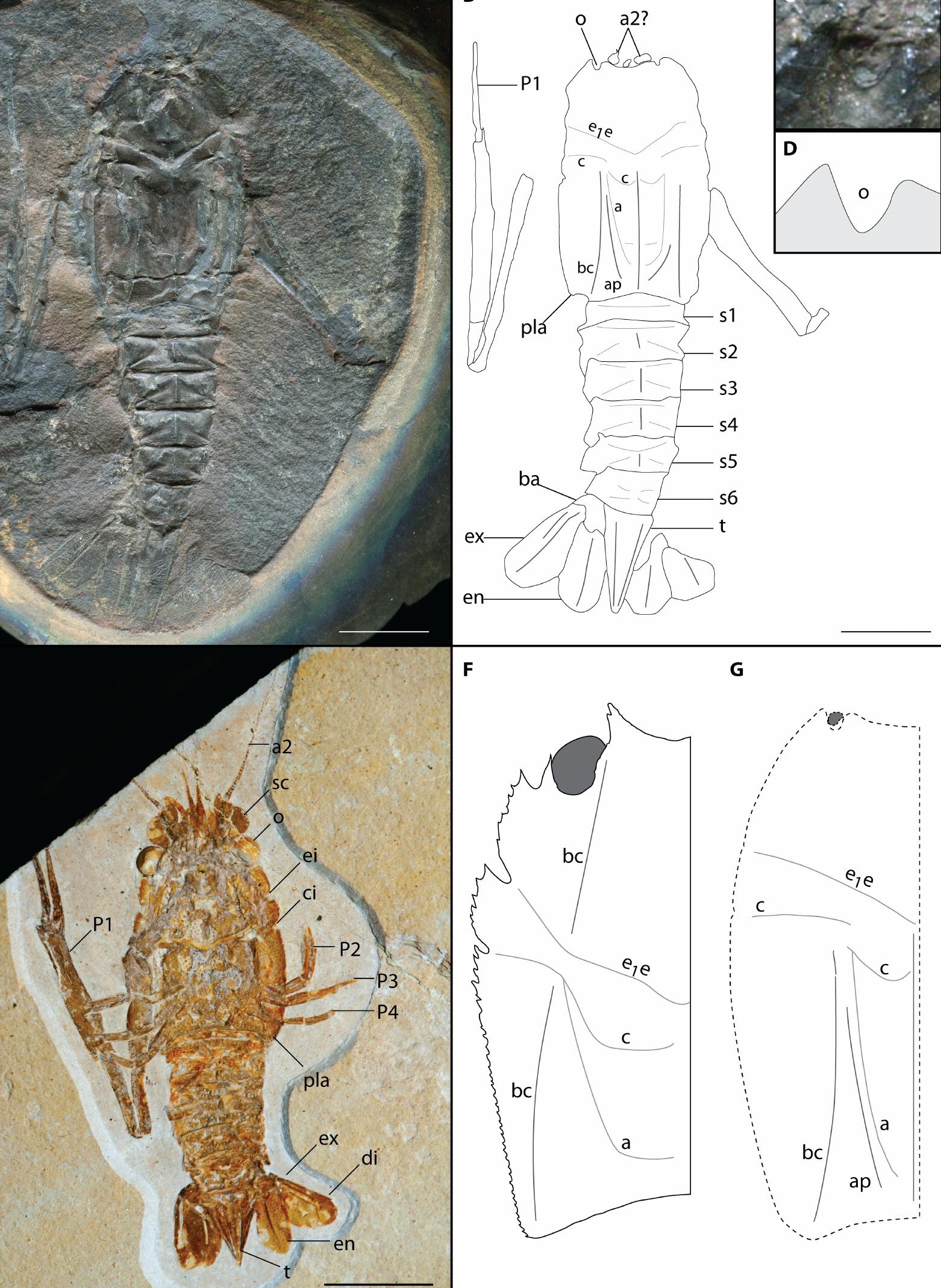




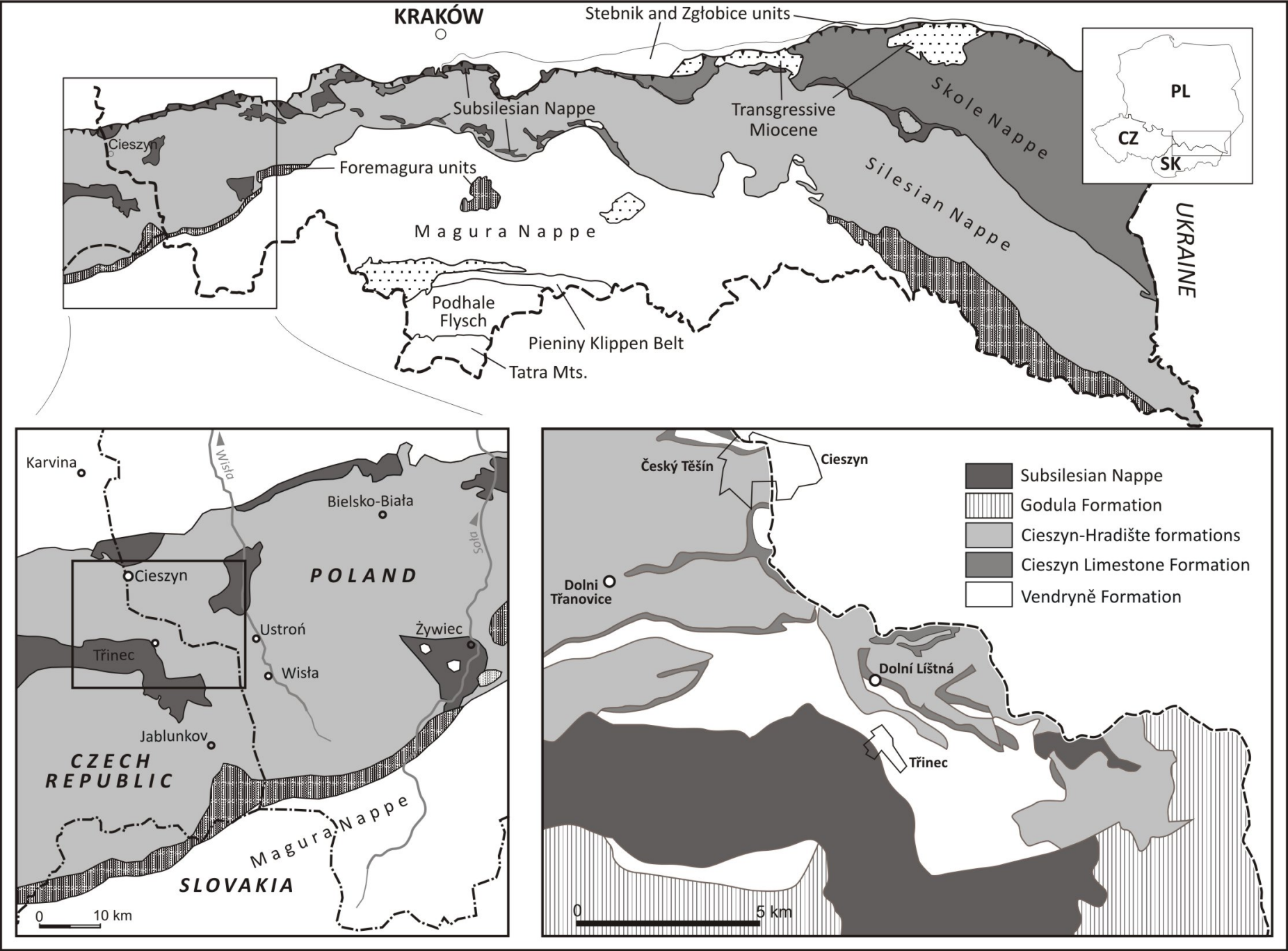




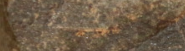

Nisis

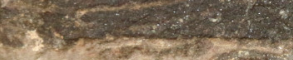

P(3)

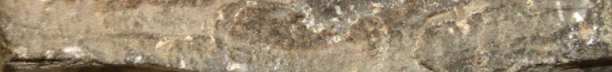

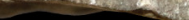

$x-2$

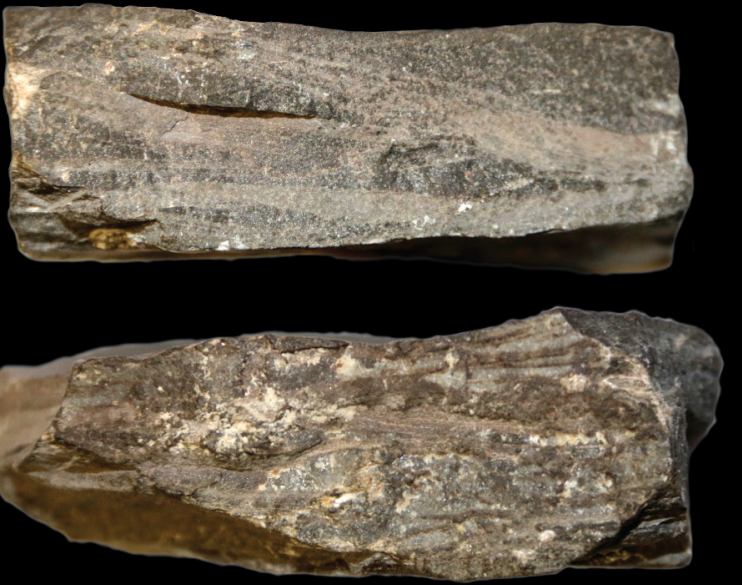




\section{Severin-Moldavidic Basin (proto-Silesian)}

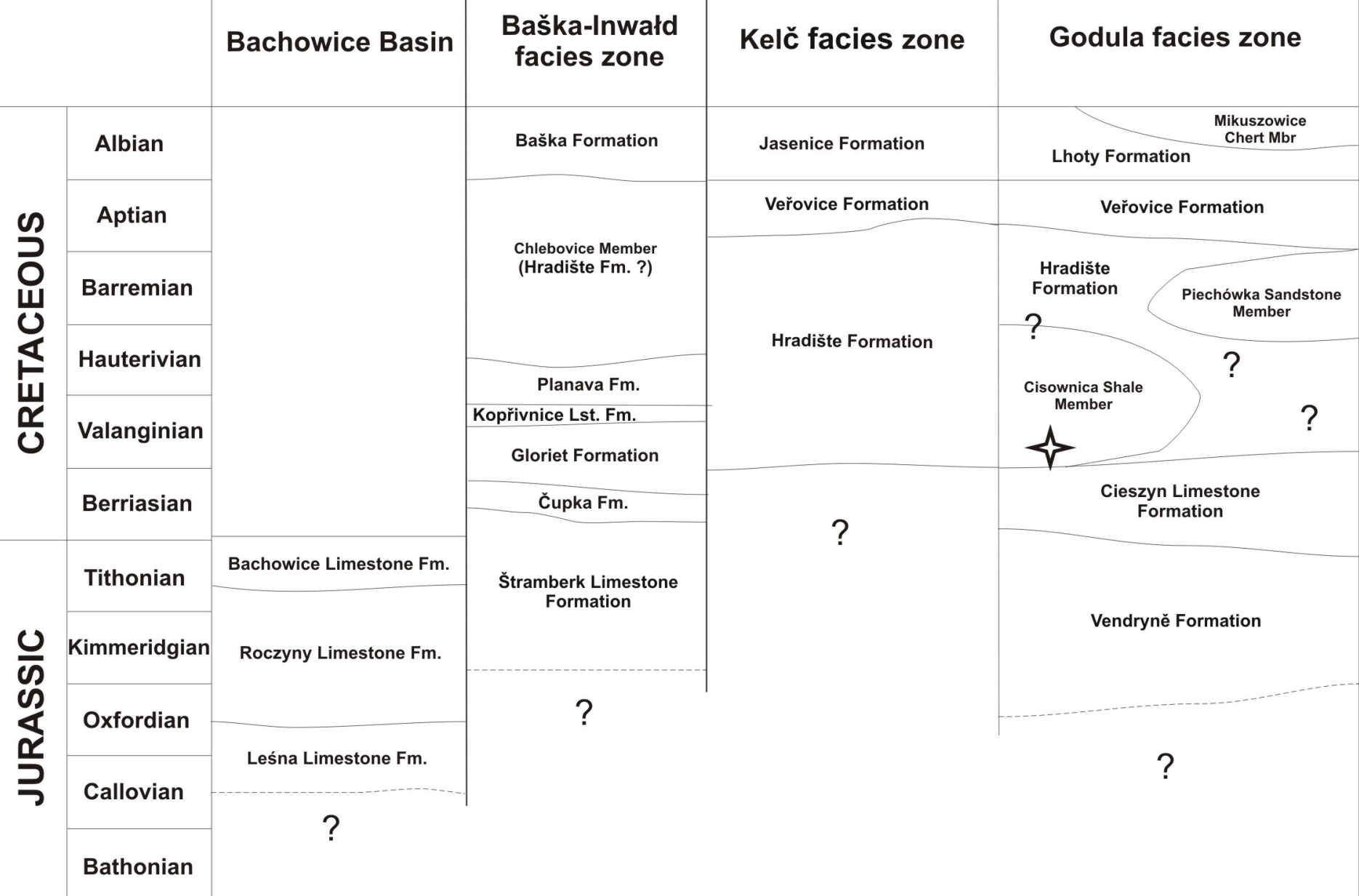

